\title{
Protein Kinase C: An Attractive Target for Cancer Therapy
}

\author{
Barbara Marengo ${ }^{1}$, Chiara De Ciucis ${ }^{2}$, Roberta Ricciarelli ${ }^{2}$, Maria A. Pronzato ${ }^{2}$, \\ Umberto M. Marinari ${ }^{2}$ and Cinzia Domenicotti ${ }^{2 *}$
}

1 G. Gaslini Institute, L.go G. Gaslini 5, 16147, Genoa, Italy; E-Mail: bmare2002@yahoo.it

2 Department of Experimental Medicine, General Pathology Section, University of Genoa, Via L.B. Alberti 2, 16132, Genoa, Italy; E-Mails: cdeciucis@yahoo.it (C.D.C.); maidep@unige.it (M.A.P.); ricciarelli@medicina.unige.it (R.R.); umm@unige.it (U.M.M.)

* Author to whom correspondence should be addressed; E-Mail: Cinzia.Domenicotti@unige.it; Tel: +39010 3538830; Fax: +390103538836.

Received: 23 December 2010; in revised form: 19 January 2011 / Accepted: 26 January 2011 / Published: 1 February 2011

\begin{abstract}
Apoptosis plays an important role during all stages of carcinogenesis and the development of chemoresistance in tumor cells may be due to their selective defects in the intracellular signaling proteins, central to apoptotic pathways. Consequently, many studies have focused on rendering the chemotherapy more effective in order to prevent chemoresistance and pre-clinical and clinical data has suggested that protein kinase $\mathrm{C}$ (PKC) may represent an attractive target for cancer therapy. Therefore, a complete understanding of how PKC regulates apoptosis and chemoresistance may lead to obtaining a PKC-based therapy that is able to reduce drug dosages and to prevent the development of chemoresistance.
\end{abstract}

Keywords: apoptosis; PKC; cancer; chemoresistance

\section{The PKC Family: Its Structure and Activation}

Protein kinase C (PKC) was originally discovered by Yasutomi Nishizuka in 1977 as a histone protein kinase activated by calcium and diacylglycerol (DAG), phospholipids and/or phorbol esters [1]. It is known that the PKC family consists of serine/threonine-specific protein kinases that differ in their structure, cofactor requirement and substrate specificity [2]. Due to biochemical 
properties and sequence homologies, $\mathrm{PKCs}$ are divided into three subfamilies: firstly, classical or conventional PKCs (cPKCs; PKC $\alpha$, PKC $\beta I, P K C \beta I I$ and PKC $\gamma$ ), which are calcium dependent and activated by both phosphatidylserine (PS) and DAG. Secondly, novel PKCs (nPKCs; PKC $\delta$, PKC $\varepsilon$, $\mathrm{PKC} \eta$ and $\mathrm{PKC} \theta$ ), which are calcium independent and regulated by DAG and PS, and finally, atypical PKCs (aPKCs; PKC $\zeta$ and PKC $\lambda$ ), which are calcium-independent and do not require DAG for activation, although PS can regulate their activity [3-5].

PKC isoenzymes share the same structural properties (Figure 1), namely, a carboxyl-terminal kinase domain linked by a flexible hinge-segment to an amino-terminal region containing regulatory modules [6,7]. These regulatory modules confer sensitivity to the DAG (C1 domain) or $\mathrm{Ca}^{2+}(\mathrm{C} 2$ domain), although some isoenzymes have variants of these modules that do not bind ligands [8]. cPKCs contain both $\mathrm{C} 1$ and $\mathrm{C} 2$ domains, $\mathrm{C} 1$ that binds DAG and phosphatidylserine, $\mathrm{C} 2$ that binds anionic lipids in a $\mathrm{Ca}^{2+}$-dependent manner [9]. The $\mathrm{C} 1$ domain, with cysteine-rich zinc finger structures, is also the binding site for the tumor-promoting phorbol esters [10] which competitively bind with DAG [11]. nPKCs contain tandem $\mathrm{C} 1$ domains that bind DAG and a variant of the C2 domain that is unable to link $\mathrm{Ca}^{2+}$ and, as a result, these isoenzymes are not sensitive to $\mathrm{Ca}^{2+}$, but their affinity for DAG is two orders of magnitude higher than that for the cPKCs [12]. aPKCs contain a variant of the $\mathrm{C} 1$ domain that binds PIP3 or ceramide (not DAG or PMA) and a protein-protein interaction PB1 (Phox and Bem 1) domain that mediates interactions with other PB1-containing scaffolding proteins including p62, partitioning defective-6 (PAR-6) and mitogen-activated protein kinase (MAPK) modules like MEK5 [13,14].

All isoenzymes have a conserved carboxyl-terminal tail (CT) that serves as a phosphorylationdependent docking site for key regulatory molecules and an autoinhibitory pseudosubstrate sequence that maintains PKC in an inactive state.

Situated between the regulatory domain and the catalytic domain, is the V3 region, which is accessible to proteolytic cleavage upon activation and conformational change of PKC [15]. Cleavage at this site leads to the release of a constitutively active catalytic domain, suggesting that many inhibitory intra-molecular interactions occur between the regulatory and catalytic domains.

PKCs may acquire the stability and the catalytic competence by a process of maturation consisting of constitutive phosphorylations [6,16]. Recently, the central role of heat shock protein-90 (HSP90) and of the mammalian target of rapamycin complex 2 (mTORC2) in this maturation process has been demonstrated $[17,18]$. Once fully processed and phosphorylated, PKCs can respond to second messengers and can also phosphorylate downstream targets. Activated PKCs are subject to down-regulation by ubiquitination and proteasomal degradation after prolonged activation with tumor-promoting phorbol esters, as well as to phosphatase activity [19]. In this regard, it has been demonstrated that the $\mathrm{PH}$ domain leucine-rich repeat protein phosphatase (PHLPP) regulates the dephosphorylation step, preceding the downregulation of PKC [20]. This process represents the termination of the life cycle of conventional and novel PKC isoenzymes. In the absence of chronic stimulation, these PKC isoforms have a long half-life whereas sustained activation with phorbol esters results in their rapid degradation [21]. 
Figure 1. Schematic representation of protein kinase $\mathrm{C}(\mathrm{PKC})$ isoenzyme structure and classification. The PKC family is divided into three subfamilies: classical (cPKCs; PKC $\alpha$, PKC $\beta I, P K C \beta I I$ and PKC $\gamma$ ), novel PKCs (nPKCs; PKC $\delta, P K C \varepsilon, P K C \eta$ and PKC $\theta$ ) and atypical PKCs (aPKCs; PKC $\zeta$ and PKC $\lambda$ ). PKC has four conserved domains (C1-4): $\mathrm{C} 1$ has cysteine-rich motifs that form the diacylgylcerol (DAG) and phorbol ester binding site; $\mathrm{C} 2$ contains the recognition site for acidic lipids and calcium binding site; C3 and C4 form the ATP and substrate binding sites.

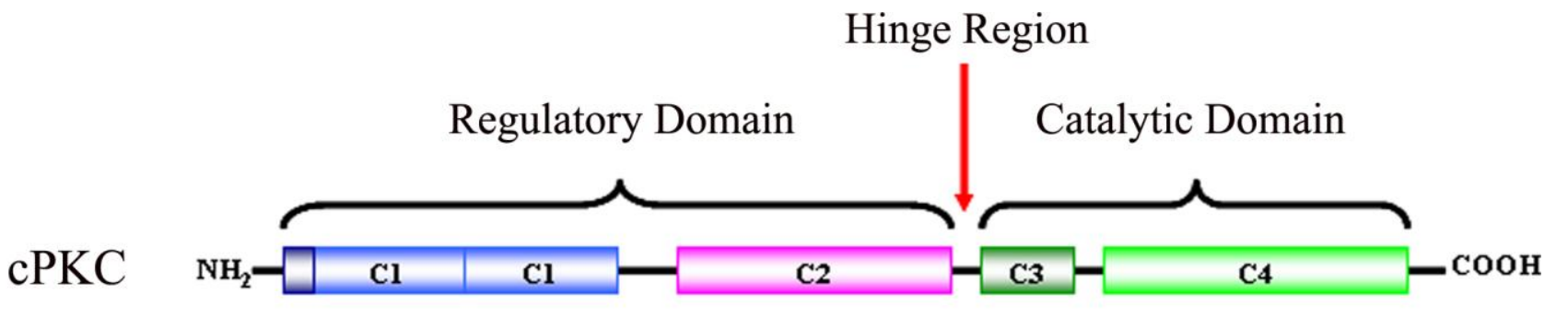

$\mathrm{nPKC} \quad \mathrm{NH}_{2}-\mathrm{Simil- \textrm {C } 2}-\mathrm{Cl}-\mathrm{Cl}-\mathrm{C3}-\mathrm{C4}-\mathrm{COOH}$

aPKC

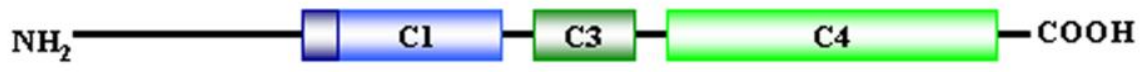

Pseudosubstrate domain

Cystein-rich region
Catalytic Domain

Catalytic Domain

Calcium-binding domain

PKCs are subject to a complicated cellular redox regulation. Selective oxidative modification at the $\mathrm{N}$-terminal regulatory domain induces PKC activation [22] while alterations at the C-terminal catalytic domain result in complete inactivation of the kinase [23]. Oxidant treatment of PKC produces a form that does not bind phorbol esters and is catalytically active in the absence of calcium and phospholipids. PKC catalytic domains are inactivated by the loss of free sulphydryl groups required for its function, thus making PKC a potential target for anticancer agents, as well as tumor promoters [24].

Studies in vivo and in vitro confirm the biphasic behavior of $\mathrm{PKC}$ in response to different oxidative damages. High doses of pro-oxidant compounds (carbon tetrachloride, ethanol) cause hepatic PKC inactivation and proteolytic degradation, while low doses induce stimulation of kinase activity [25].

Indeed, Ward et al. have suggested that depletion of GSH during oxidative stress removes a mechanism for negative regulation of PKC and, consequently, provides a permissive environment for PKC activity and tumor promotion [26].

Consistent with their different biological functions, PKC isoforms differ, not only in their structure and mode of activation, but also in their tissue distribution, subcellular localization and substrate specificity. The activation of PKC isoenzymes results in changes in their subcellular location following 
translocation to specific anchoring proteins, collectively named, "receptors for activated C kinases" (RACKs) [27]. RACKs act as molecular scaffolds that are able to localize specific PKCs to distinct membrane microdomains in close proximity with their allosteric activators and unique intracellular substrates. Moreover, it has been discovered that the $\mathrm{C} 2$ domain is the region within the regulatory domain of PKC that interacts with RACKs [28,29].

More information about PKC subcellular localization has also been obtained from several studies in which phorbol esters were employed to translocate single PKC isoforms to a specific cellular compartment. In particular, TPA (12-O-tetradecanoyl-phorbol-13-acetate) induced the translocation of $\mathrm{PKC} \alpha$ and $\mathrm{PKC} \delta$ from the cytosol to the plasma membrane and nucleus [30,31] and of PKCE to the Golgi membranes, thereby modulating Golgi functions [32]. However, in the last twenty years, use of green-fluorescent-protein (GFP) fusion proteins have facilitated the monitoring of the PKC's localization in living cells [33,34].

PKC isoenzymes modulate a plethora of biological functions, including cell growth, differentiation, apoptosis, transformation and tumor development [35]. Nevertheless, the way in which PKC isoform specificity in vivo covers these processes is not clear, since all cells and/or tissues express more than one PKC isoform that acts in a redundant manner [36]. Due to the signaling amplitude of PKC being ultimately dependent on the levels of PKC poised in the cell, targeting mechanisms that control the levels of PKC offer an alternative approach to controlling PKC signaling.

\section{PKC Isoforms: Physiological Functions and Role on Cancerogenesis}

The tumor promoting properties of phorbol esters have been known for many years and are well documented in animal models of human cancer. The discovery of PKC, as the phorbol ester "receptor", has led to a heightened interest in the contribution of these kinases to tumorigenesis and tumor progression [37,38].

Overall, the function of PKC in cancer is complex because much of the data indicate that the isoenzymes subtly regulate many pathways involved in cellular transformation [39].

The PKC isoforms most commonly associated with increased proliferation and/or survival, PKC $\alpha$ and $\varepsilon$, are most overexpressed in human cancer and represent potential oncogenes.

PKC $\alpha$ has been associated with several cell functions and its activation with phorbol ester tumorpromoters is associated with the inactivation of E-cadherin, a key factor in the regulation of cell to cell contact, leading to multi-layered cell growth [40]. Furthermore, PKC $\alpha$ modulates membrane re-modeling by stabilizing F-actin and this effect is in opposition to that of PKCE, which induces early actin disruption and basolateral membrane endocytosis [41].

Interesting studies have demonstrated that the $\alpha$ isoenzyme may act as a tumor promoter or as a tumor suppressor [42]. For example, overexpression of $\mathrm{PKC} \alpha$ has been demonstrated in tissue samples of prostate, endometrial and high-grade urinary bladder $[43,44]$, up- or down-regulation of PKC $\alpha$ has been observed for hematological malignancies [45] while down-regulation of PKC $\alpha$ has been described in basal cell carcinoma and colon cancers [46,47].

This isoform has been studied extensively in breast cancer cells and contradictory results have been found [48-50]. Recently, it has been reported that PKC $\alpha$ activity supports migration of breast cancer 
cells in vitro and its overexpression correlates to tumor grade, proliferating activity and poor prognosis [51].

In addition, PKC $\alpha$ overexpression is correlated with tumor size and the TNM stage of hepatocellular cancer (HCC) and its levels may be a prognostic marker also in these patients [52]. Consequently, strategies to reduce the expression of this isoenzyme might be useful in cancer therapy. However, since PKC $\alpha$ plays multiple roles in cell physiology and pathology, targeting its downstream signals may be even more beneficial than just targeting the specific isoform. In this regard, it has been demonstrated that the suppression of p38MAPK markedly reduced the invasiveness of human HCC cells [53].

Overexpression of PKC $\beta$ can contribute in several ways to tumor formation, being involved in tumor host mechanisms such as inflammation [54] and angiogenesis in breast cancer [55] and in retinal tissue [56]. Elevated expression of PKC $\beta$ seems to be an early event in colon cancer development [57] and transgenic overexpression of PKC $\beta I$ in the intestine induces hyper-proliferation and an invasive phenotype in epithelial cells [58,59]. Consistent with this, the PKC $\beta$ specific inhibitor enzastaurin inhibits the activation of the AKT-GSK3 dependent survival pathway in colon cancer cells, as well as in mouse xenograft models [60].

In patients with diffuse large B-cell lymphoma, $\mathrm{PKC} \beta$ is one of the most overexpressed genes [61] while the loss of PKC $\beta$ expression has been observed in melanoma cell lines [62].

$\mathrm{PKC} \gamma$ is mainly expressed in neuronal tissues [63] and there is little information regarding its role in tumor formation. Cell transformation of mammary epithelial cells following PKC $\gamma$ overexpression has been described, but it is not known whether this contributes to breast cancer formation [64]. Surprisingly, PKC $\gamma$ has been shown to be a positive prognostic factor for some forms of B-cell lymphomas [65].

PKC $\delta$, a ubiquitously-expressed isoenzyme, is implicated in various cellular processes such as proliferation, differentiation and apoptosis. The diverse effects that $\mathrm{PKC} \delta$ could exert on cell survival are dependent on its subcellular localization. For example, the $\delta$ isoenzyme translocates to the Golgi in response to IFN- $\gamma$ and ceramide [66], to the nucleus in response to etoposide and irradiation [67] and to the mitochondria in response to UV radiation, phorbol 12-myristate 13-acetate and oxidative stress [68]. In this regard, we have previously shown that glutathione (GSH) depletion induced by L-buthionine-S,R-sulfoximine (BSO) in neuroblastoma cells caused ROS overproduction, PKC $\delta$ translocation to the mitochondria and apoptosis [69].

Analyzing the role of PKC $\delta$ in cancer progression, PKC $\delta$ can act as either a positive or a negative regulator of tumor progression [70]. In this context, it has been demonstrated that the down-regulation of PKC $\delta$ with prolonged phorbol-ester treatment of Src-overexpressing fibroblasts confers a malignant phenotype [71], suggesting a tumor-suppressor role for this isoform. On the other hand, it has been found that pro-tumorigenic sonic hedgehog ( $\mathrm{SHH}$ ) signaling and Wnt signaling are dependent on PKC $8 / E R K$ pathways [72].

In relation to specific types of malignancy, $\mathrm{PKC} \delta$ may be overexpressed in colon cancers and down-regulated in malignant gliomas, bladder carcinomas and endometrial tumors [73,74]. Recently, the expression of PKC $\delta$ in human breast cancer has been investigated and an association between elevated PKC $\delta$ expression and a poor outcome has been found [75]. Moreover, PKC $\delta$ is likely to play 
a major role in anti-estrogen resistance in breast cancer cells and has been linked with acquired resistance to tamoxifen in breast cancer patients [76].

Conversely, PKC $\delta$ activation in prostate cancer serves to promote extrinsic apoptosis through the release of death receptor ligands [77]. Since androgens modulate PKC $\delta$ at a transcriptional level, both androgen depletion and androgen receptor RNA interference that suppress the $\delta$ isoenzyme triggered apoptosis, suggesting that the hormonal regulation might be a therapeutic approach to modulate $\mathrm{PKC} \delta$ and its downstream signals [78].

In addition, the overexpression of PKC $\delta$ in human cutaneous squamous carcinoma (SCC) cell lines induced apoptosis and suppressed tumorigenicity, making $\mathrm{PKC} \delta$ a potential tumor suppressor gene for SCCs. In this regard, it has been recently demonstrated that PKC $\delta$ gene expression is suppressed in human SCCs, probably via transcription repression [79].

On the contrary, this isoform was overexpressed in human ductal carcinomas and the stable overexpression of this kinase in a human pancreatic carcinoma cell line (PANC1) induced a more malignant phenotype when these cells were inoculated into nude mice [80]. PKC $\delta$ has also been linked to an inhibitory role in cell autophagy, suppressing the catabolic process in pancreatic cancer [81].

$\mathrm{PKC} \varepsilon$ is the only isoenzyme that has been considered as an oncogene [82] and the first hint that PKCE may be involved in malignancy came from the study of Baxter et al. [83]. In addition, it has been seen that overexpression of PKC $\varepsilon$ in NIH 3T3 fibroblasts caused increased saturation density, facilitating growth in soft agar and induced tumor formation in nude mice [84].

Similarly, it has been found that the overexpression of this isoform conferred a metastatic phenotype to colonic epithelial cells $[85,86]$. In addition, PKC $\varepsilon$ has been shown to be an important mediator of squamous cell carcinogenesis and its overexpression in mouse epidermis caused development of SCC following application of dimethylbenz(a)anthracene and TPA protocol or ultraviolet radiation [87]. The level of PKC $\varepsilon$ was also increased in primary high-grade astroglial brain tumors [88] and overexpression of dominant-negative PKC $\varepsilon$ inhibited proliferation of human astrocytoma cells [89]. Moreover, PKC $\varepsilon$ activation has been linked with invasiveness of human renal cell carcinomas [90] and with aggressive, motile phenotype in breast cancer cells [86] and in human head and neck squamous cell carcinoma [91].

Although, the way in which PKCe modulates cell motility is not completely defined, it has been observed that $\mathrm{PKC} \varepsilon$ promotes actin polymerization [92] and it drives cell motility, in part, through the downstream activation of small Rho GTPases, specifically RhoA and/or RhoC [86], the phosphorylation of Akt [93] and of Stat3 [94].

Overexpression of PKC $\varepsilon$ has been found in human prostatic tumors and it is associated with the conversion from an androgen-dependent to androgen-independent state [95]. The PKC $\varepsilon$ gene is also amplified in $28 \%$ of thyroid cancers and a chimeric/truncated version of this isoform has been cloned from human thyroid cancer cells [96]. At present, there is no existing literature to document PKC $\varepsilon$ overexpression in samples from patients with hematopoietic cancers [97].

\section{PKCs: a Cell "Fulcrum" Able to Modulate Apoptosis and Cell Survival}

Apoptosis is a multi-stage process that is vital for the maintenance of homeostasis in multicellular organisms. However, in cancer, the evasion from the programmed cell death plays a role in 
chemoresistance. In this regard, it has, in fact, been demonstrated that the activation of PKCs can be associated with resistance but can also increase sensitivity to chemotherapy [98]

From this point of view, PKCs act as a "fulcrum" that is able to up- or down-regulate the signaling pathway, resulting in cell proliferation or apoptosis. In this section, the most intriguing evidence about the relative contribution of each PKC isoenzyme to cell survival and death pathway is summarized.

PKC $\alpha$ has emerged as an important isoform in promoting cell survival. In several cell lines, including endothelial cells [99] and glioma cells [100,101], apoptosis was induced as a result of cellular PKC $\alpha$ depletion. Although the mechanism by which PKC $\alpha$ prevents apoptosis is only partially known, one target that has been identified is the anti-apoptotic Bcl-2 protein. In HL-60 cells, PKC $\alpha$ colocalized with Bcl-2 in the mitochondria [102] while other experiments, with murine growth factordependent cell lines, demonstrated that PKC $\alpha$ phosphorylated Bcl-2 at Ser70 [103]. Phosphorylation of this site had the effect of stabilizing Bcl-2 and enhancing its ability to prevent apoptosis. Another possible target for PKC $\alpha$ is $\mathrm{Raf}-1$, which has been shown to mediate the anti-apoptotic function of $\mathrm{PKB} / \mathrm{Akt}$ in hematopoietic cells through a PKC-dependent mechanism [104]. From this prospective, in various types of cancer cells, this anti-apoptotic role of $\mathrm{PKC} \alpha$ resulted in an increase in cell proliferation [105] and survival [106]. In this regard, it has been demonstrated that the antisense of $\mathrm{PKC} \alpha$ inhibits cell proliferation in vitro and tumorigenicity in vivo in nude mice xenografts of human glioblastoma and lung cancer cells $[107,108]$. In addition, microinjection of antibodies against PKC $\alpha$ also inhibits cell growth and differentiation of neuroblastoma cells [109]. Moreover, PKC $\alpha$ knockdown impaired tumor growth and reduced the activation of Akt and ERK, suggesting that PKC $\alpha$ is an upstream regulator of these critical growth and survival signaling pathways [110]. Although the majority of published work suggests a suppressive role for $\mathrm{PKC} \alpha$ in apoptosis, conflicting data, indicating a pro-apoptotic function, has been observed. In human prostate cancer cell lines, the presence of PKC $\alpha$ in the mitochondrial membrane was associated with apoptosis while its absence corresponded to resistance to cell death [111]. In addition, PKC $\alpha$ was shown to mediate the activation of caspase-3 in renal proximal tubule cells treated with cisplatin [112]. Furthermore, the stable overexpression of PKC $\alpha$ in LNCaP cells, a widely used cellular model of androgen-dependent prostate cancer, suggested that the activation of this isoenzyme was critical to the PMA apoptotic response [111]. This particular study demonstrated a strong correlation between the presence or absence of PKC $\alpha$ in the membrane and the apoptosis induction or resistance, respectively. Moreover, it has been reported that $\mathrm{PKC} \alpha$ can also exert growth inhibitory functions in intestinal, pancreatic and mammary cells [113-115]. In the case of intestinal cells, PMA treatment causes cell-cycle arrest in G1 in a PKC $\alpha$-dependent manner. G1 arrest occurs with a corresponding increase in the expression levels of the cyclin-dependent kinase inhibitors p21 and p27, a decrease in retinoblastoma (RB) phosphorylation and a sustained ERK activation $[115,116]$. Recent studies carried out by using the PKC $\alpha$ null mouse [47] and the phenotypical analysis of PKC $\alpha$ knockouts in colorectal cancer [36] have suggested that PKC $\alpha$ has a role in tumor suppressor. On the basis of these findings, it is clear that $\mathrm{PKC} \alpha$, in a tumor-specific manner, assumes different roles in the control of cell survival and death, but not only, since PKC $\alpha$ also plays a critical role in the induction of chemosensitivity. Specifically, it confers resistance to drugs like cisplatin in prostate cancer cells [117], etoposide in leukemia cells [103] and tamoxifen in breast cancer cells [118]. 
PKC $\beta$ I and PKC $\beta$ II derive from a single gene by alternative splicing and are differentially involved in cell growth and apoptosis [119,120]. Initial studies have demonstrated that PKC- $\beta$ II promotes cellular proliferation in human leukemia cells and colon cancer cell lines [121,122] and a positive effect of PKC- $\beta$ I on the growth and proliferation of neuroblastoma cells has been found [123]. Subsequent studies have shown that the expression of PKC $\beta$ II in the colon of transgenic mice leads to hyperproliferation and increased susceptibility to colon carcinogenesis [57,124], whereas PKC $\beta$ I seems to act as a survival mediator in response to chemotherapeutic agent-induced apoptosis in gastric cancer $[125,126]$. In addition, the expression of the oncogene v- $a b l$ causes translocation of PKC $\beta$ II to the nucleus, thereby preventing apoptosis and confirming that PKC $\beta I I$ is anti-apoptotic [127]. Moreover, a mitotic lamin kinase has been identified as a target for PKC $\beta I I$, and its interaction with this substrate promotes cell survival and proliferation [128,129]. In fact, lamin B is phosphorylated by the PKC $\beta$ II after treatment with bryostatin [130], an activator of PKC, and this phosphorylation leads to the solubilization of lamin B.

Possible pro-apoptotic activity of PKC $\beta$ has also been reported. Activation of PKC $\beta$ I by 12-deoxyphorbol 13-phenylacetate 20-acetate (DOPPA), which is a selective activator of this isoform in vitro, induced apoptosis in HL60 cells [131] indicating that PKC $\beta I$ and PKC $\beta I I$ might have opposite roles in the regulation of apoptosis. In a subsequent study, $\mathrm{PKC} \beta$ was demonstrated as being necessary in the targeting of stress-activated protein kinase (SAPK) to the mitochondria [132]. SAPK was shown to, not only interact with, but also phosphorylate the anti-apoptotic Bcl-2 family member Bcl-x(L) in the mitochondria, resulting in promoting the release of cytochrome $\mathrm{c}$.

The activation of PKC $\delta$ is associated with the inhibition of cell cycle progression and its downregulation is linked to tumor promotion, suggesting that $\mathrm{PKC} \delta$ may have a negative effect on cell survival [70,133]. In many cases, the growth-inhibitory effects of $\mathrm{PKC} \delta$ have been linked to changes in the expression of factors that influence cell cycle progression. Furthermore, we know that PKC $\delta$ plays an essential role in the genotoxic stress response leading to apoptotic cell death in many cell types. In fact, PKC $\delta$ is activated by numerous apoptotic stimuli, including genotoxins [67], oxidative stress $[68,69,134]$ and death receptors [135]. Conversely, the inhibition of PKC $\delta$ with rottlerin or the expression of PKC $\delta \mathrm{KD}$ (kinase dead $\mathrm{PKC} \delta$ ) inhibits apoptosis induced by a variety of stimuli [136]. Depending on the cell types and apoptotic stimuli, $\mathrm{PKC} \delta$ translocates to nearly all subcellular organelles, including the nucleus [137], mitochondria [138], Golgi complex, endoplasmic reticulum and plasma membrane [139]. At each subcellular organelle, PKC $\delta$ phosphorylates different substrates leading to cell death. Whilst the identification of these substrates is critical in order to understand the mechanism of $\mathrm{PKC} \delta$, it has been very challenging to identify physiologic substrates in each organelle. Furthermore, although putative PKC $\delta$ substrates have been identified in apoptotic cells, the molecular mechanisms through which $\mathrm{PKC} \delta$ regulates apoptosis are not known. Nuclear proteins comprise the largest group of PKC $\delta$ substrates identified in apoptotic cells. These include lamin B, the checkpoint protein hRad9 and DNA protein kinase, all of which have been shown to be phosphorylated by $\mathrm{PKC} \delta$ in genotoxin-treated cells [140,141]. PKC $\delta$ may also regulate the transcription of death genes through activation or inactivation of transcription factors such as p53, p73 and STAT1 [142,143]. In this regard, it has been demonstrated that TP53 functions as a novel nuclear effector of PKC $\delta$-mediated apoptosis [144]. Specifically, PKC $\delta$ activates transcription factor Btf to bind with the TP53 promoter. Moreover, the disruption of Btf-mediated TP53 gene transcription leads to the suppression of 
TP53-mediated apoptosis following genotoxic stress [145]. Interestingly, it has been demonstrated that PKC $\delta$ regulates p53 not only that at transcriptional level, but also at post-translational levels. For example, in smooth muscle cells apoptosis is triggered by a pathway that involves PKC $\delta$, the intermediary p38 MAPK, and the downstream target tumor suppressor p53 [146]. In another study, carried out on dopaminergic neurons, it has been shown that nitration-mediated activation of $\mathrm{PKC} \delta$ induces the phosphorylation of p53 at the Ser15 residue, which increases its protein stability, thereby contributing to the nitric oxide-mediated apoptosis [147]. PKC $\delta$ also activates the JNK pathway through phosphorylation and activation of MEKK1 (MEK kinase 1) [148]. In addition, PKC $\delta$ has been reported to interact with c-Abl in response to both genotoxic and oxidative stress [149]. Significantly, other studies have identified reciprocal regulation of $\mathrm{PKC} \delta$ by $\mathrm{NF}-\kappa \mathrm{B}$ by showing that a $\mathrm{NF}-\kappa \mathrm{B}-$ responsive regulatory element in the PKC $\delta$ promoter links TNF $\alpha$ stimulation to an increase in PKC $\delta$ mRNA and protein expression [150].

However, the ability of PKC $\delta$ to activate an apoptotic program is regulated by three key steps. Firstly, the transduction of a "death" signal to PKC $\delta$ by a DNA damage sensor pathway that may occur via phosphorylation of PKC $\delta$ at specific residues [151]. Secondly, the transitory accumulation of the activated PKC $\delta$ in the nucleus where it is cleaved by caspase 3 [142], and finally, the nuclear accumulation of $\mathrm{PKC} \delta$ resulting in the cells undergoing apoptosis [137]. In regard to these events, it has recently been found that $\mathrm{PKC} \delta$ contains a nuclear localization sequence that is required for its nuclear import. Moreover, it has been proposed that PKC $\delta$ full-length (FL) may act as an apoptotic sensor, since its nuclear accumulation precedes the activation of any of the known components of the apoptotic pathway in etoposide-treated parC5 cells [136]. In the absence of an apoptotic signal, PKC $\delta$ is retained in the cytosol while apoptotic signals, such as etoposide, induce post-translational modifications in the PKC $\delta$ which may allow its nuclear accumulation [152]. Active caspase 3 also accumulates in the nucleus in response to etoposide, resulting in the cleavage of PKC $\delta$ and generation of the $\delta$ catalytic-fragment $(\mathrm{CF})$. In contrast with $\mathrm{PKC} \delta \mathrm{FL}, \delta \mathrm{CF}$ is constitutively present in the nucleus, where it presumably regulates apoptosis through the phosphorylation of proteins involved in cell damage, as well as other apoptotic mediators. On the basis of these findings, it is possible to suggest that a strict regulation of nuclear import and export of PKC $\delta$ is critical for cell survival and that caspase cleavage of PKC $\delta$ in the nucleus signals an irreversible commitment to apoptosis [152].

In addition to its apoptotic functions, $\mathrm{PKC} \delta$ has also been reported to exert antiapoptotic effects. Thus, PKC $\delta$ protects macrophages from apoptosis induced by nitric oxide [153] and exerts antiapoptotic effects on glioma cells treated with TRAIL [154].

Similarly, PKC $\delta$ promotes survival and chemotherapeutic drug resistance of non-small cell lung cancer cells [155]. As previously described in this section, one of the factors that may contribute to the diverse effects of PKC $\delta$ on cell fate is its different subcellular localizations. In fact, on one hand, the translocation of PKC $\delta$ to the Golgi, mitochondria and nucleus has been associated with proapoptotic effects [155]. On the other hand, its translocation to the endoplasmic reticulum (ER) results in antiapoptotic effects [154]. The role of PKC $\delta$ in the ER and the mechanisms involved in its antiapoptotic effects are currently not fully understood. However, there are several apoptosis-related proteins which reside in the ER and play an important role in the regulation of cell survival. One possible PKC $\delta$ substrate in the ER is Bcl2, which regulates the "cross-talk" between the ER and the mitochondria during cell apoptosis [156]. Moreover, the phosphorylation of AKT [154] and 
HSP25 [157] is associated with the antiapoptotic effects of PKC $\delta$. Finally, a novel PKC $\delta$ isoenzyme, PKC $\delta$ VIII, has been recently identified in human teratocarcinoma (NT2) cells [158]. In both in vivo and in vitro assays, PKC $\delta$ VIII has been demonstrated to be resistant to caspase- 3 cleavage. In addition, the overexpression or down-regulation of the PKC $\delta$ VIII isoenzyme suggests its antiapoptotic function. On the basis of this information, it is possible to assume that PKC $\delta$-dependent signaling not only represents a mechanism for protecting cells from stress conditions and a mechanism for promoting apoptosis to eliminate irreversibly damaged cells, but also provides a mechanism for switching or regulating cells between survival and death.

Involvement of PKC $\varepsilon$ in the apoptotic pathways has been disclosed in cancer research $[159,160]$ and supported by the finding that PKCe knockout mice exhibited significantly decreased survival [161]. Several studies demonstrated that PKCE plays a protective role during receptormediated cell death and it has been reported that cellular susceptibility to TRAIL correlates with PKC $\varepsilon$ level [162]. In fact, introduction of dominant-negative PKC $\varepsilon$ [163] or knockdown of PKC $\varepsilon$ [154] sensitized glioma cells to apoptosis. Moreover, PKC $\varepsilon$ not only regulates apoptosis but it is also cleaved by caspases in response to several apoptotic stimuli, including chemotherapeutic agents, starvation and TNF [160]. Contradictory results have been obtained about the role of caspase-mediated PKC $\varepsilon$ cleavage and apoptosis, suggesting that the cellular context may play an important role in deciding whether proteolytic cleavage of PKC $\varepsilon$ will induce, inhibit or have no effect on apoptosis.

From several studies it appears clear that the antiapoptotic effects of PKC $\varepsilon$ were mediated by an increase in Akt phosphorylation and activity [164]. In this regard, the interaction of Akt and PKCE was associated with an increase in Akt phosphorylation at Ser473 and consequently, resistance to apoptosis. Interestingly, signaling via both proteins was required for efficient MAPK activation, suggesting that the PKC $\varepsilon$-Akt complex can cross-talk with a third pathway to mediate its antiapoptotic effects [165]. PKCe may also enhance Akt activity indirectly, through a positive feed-back loop comprising also integrins [164].

Contrary to the data cited above, it has been also reported that PKCE negatively regulates Akt function and this was associated with increased apoptosis [166]. This inhibitory effect was associated with a decrease in Akt phosphorylation.

Additional studies have attributed also a regulatory role on Bcl-2 family members to PKCE. In fact, it has been shown that PKC $\varepsilon$ enhances antiapoptotic Bcl-2 members while it inhibits the proapoptotic members of this family [162]. Moreover, it has been reported that the development of pregnancydependent mammary tumors to malignant tumors was accompanied by an intense expression of Bcl-2 and was associated with the overexpression of PKCE [167] In addition, it has recently been found that overexpression of PKCE in MCF-7 cells increased Bcl-2 mRNA and protein level and, concomitantly, decreased the proapoptotic protein Bid. This dual regulation of pro- and antiapoptotic members of the Bcl-2 family contributed to TRAIL resistance. Moreover, it has been reported that PKCE-deficient cells were sensitive to PMA-induced apoptosis and the overexpression of PKC $\varepsilon$ in these cells conferred resistance to PMA-mediated apoptosis by preventing Bax activation and translocation to mitochondria [168].

Higher levels of PKCE, in small cell lung cancer (SCLC), were associated with higher Bcl-XL and X-linked inhibitor of apoptosis (XIAP) protein levels [169]. Moreover, a high percentage of patients with SCLC die in consequence of the chemoresistance that may be due to the increased expression of 
some antiapoptotic proteins [170]. The strict link between PKC $\varepsilon$ and chemoresistance has recently been demonstrated by a study of Bourgulgon et al. In particular, this study indicate that the hyaluronan (HA)-induced interaction between CD44 (a primary HA receptor) and PKC $\varepsilon$ increases the phosphorylation of the stem cell marker, Nanog. Moreover, HA-CD44-mediated PKCE-Nanog signaling mediates miR-21 production, which in turn, exerts its influence on tumor cell-specific functions, including anti-apoptosis and chemoresistance. This newly discovered PKCE-Nanog signaling pathway should provide important drug targets for sensitizing tumor cell to apoptosis and overcoming chemoresistance in HA-CD44-activated breast cancer cells [171].

\section{PKC Modulators: from the Laboratory to Its Clinical Employment}

The participation of PKC isoenzymes in cancer, either by antagonizing or promoting malignant growth, supports the notion that PKCs could be potential direct targets for anticancer therapy. In fact, several PKC modulators are currently in clinical trials as chemotherapeutic agents.

PKC inhibitor therapy is currently employed in human clinical trials, both alone and in combination with other modalities [55,172]. Different strategies have been devised in the drug development of PKC inhibitors and these include ATP and protein substrate binding pocket inhibitors, small molecule kinase inhibitors, biologic modulators of PKC and anti-sense oligonucleotides.

Staurosporine, the first reported ATP competitive PKC inhibitor [173], is produced by streptomymes $S p$ and shows an anti-proliferative action. Although this compound lacks specificity for PKC isoforms, it has served as a lead compound from which many other PKC inhibitors have been developed, among them, Midostaurin and Enzastaurin, which have been employed in anti-cancer clinical trials [174].

Midostaurin (PKC412 or n-benzoylstaurosporine), similar to UCN01 (7-hydroxystaurosporine), was the first PKC inhibitor to have been evaluated in oncology clinical trials [175].

This compound exhibits selectivity for the ATP binding sites, but shows modest isoenzyme specificity. In pre-clinical studies, midostaurin has shown a broad range of anti-tumor activities, synergizing with conventional cytotoxic agents [176,177]. From in vitro and in vivo studies, encouraging results have been obtained, in particular, it has been demonstrated that midostaurin inhibits PKC activity in melanoma cells [178] and delays the development of lung metastasis in mice [179]. Moreover, this compound has displayed some clinical activity as a single agent and was able to potentiate the anti-tumor activity of some of the clinically-used cytotoxins (Taxol® and doxorubicin) [180,181]. Midostaurin was shown to have biological activity in low grade lymphoproliferative disorders like B-chronic lymphocytic leukemia [182,183] and acute myeloid leukemia [184,185]. Midostaurin was well-tolerated in a phase I study, with the main toxicities being nausea, vomiting, diarrhea and fatigue. Therefore, a phase II trial was investigated in patients with malignant melanoma and some of them, with accessible tumors, were biopsied to examine drug efficacy. Unfortunately, in these latter studies, midostaurin failed to statistically demonstrate significant clinical activity [186].

Enzastaurin (LY317615) is an oral serine/threonine kinase inhibitor that was originally evaluated in human tumor xenograft-bearing mice for its antiangiogenic activity [187]. At low concentrations, 
enzostaurin inhibits PKC $\beta$ but, at higher concentrations, it acts unspecifically, inhibiting the other PKC isoenzymes [188].

Moreover, the anti-tumor effects of enzastaurin are mediated through interference with the phosphatidylinositol3-kinase (PI3K)/Akt pathway [60,189-191]. Several studies have shown that enzastaurin exhibits direct growth inhibiting effects on a wide array of cultured human tumor cells [60,189-193] and in animal models, it showed anti-tumor and anti-angiogenic activity in various malignancies [194]. Currently, enzastaurin is being evaluated in several clinical trials and it appears to be well-tolerated at doses from 20 to $750 \mathrm{mg} /$ day in patients with advanced solid tumors [195] and the recommended oral daily dose was $525 \mathrm{mg}$ [196]. Although this was a phase I study, several patients with lung cancer, colorectal carcinoma and renal carcinoma demonstrated prolonged disease stabilization [195].

The PKC $\beta$ and PI3K-Akt pathways are frequently activated in glioblastoma, making this an attractive tumor type in which to further investigate enzastaurin. Reports from a phase II trial in patients with recurrent high-grade gliomas were promising [197]. A phase III study showed that treatment with enzastaurin was well-tolerated and associated with prolonged freedom from progression in a small subset of patients with relapsed or refractory diffuse large B-cell lymphoma (DLBCL) [198]. Moreover, a large global phase III trial of standard induction therapy (prednisone/rituximab), with or without enzastaurin consolidation, has recently been initiated in patients with newly diagnosed, highintermediatehigh-risk DLBCL [199]. Finally, combination studies of enzastaurin with gemcitabine and cisplatin have been investigated and preliminary reports from this phase I study, look promising [200].

In conclusion, enzastaurin is a very promising anticancer agent per se and it is a good candidate for different combination regimens with other novel targeted agents and cytotoxic drugs commonly used in the clinical setting.

UCN-01 (7-hydroxystaurosporine), a staurosporine analogue isolated from the culture broth of Streptomyces species [201], is an inhibitor of cPKC and nPKC isoenzymes [202] and also of cdk1 and cdk2 [203-205]. Pre-clinical models have demonstrated synergistic activity of UCN-01 with a number of cytotoxic agents [206-208]. For this reason, several phase I studies have been conducted with UCN-01 as a single agent and in combination with cytotoxic chemotherapy [209-211]. In the singleagent phase I study, pharmacokinetic data revealed that UCN-01 has a very small volume of distribution, low systemic clearance and a prolonged half-life of elimination (>200 h) [212]. Three phase I combination studies, in which UCN-01 was combined with cisplatin [211], 5-fluorouracil [210] and topotecan [213] involving patients with solid tumors have been carried out. Moreover, this compound is currently being employed in clinical trials for leukemia, non-small cell lung cancer (NSCLC), and lymphoma.

Bryostatins are a family of at least 20 macrocyclic lactones derived from the marine bryozoan Bulgula neritina [214]. Bryostatin is an activator of DAG/phorbol ester sensitive PKC isoforms and induces differential downregulation of isoforms in cells causing suppression of selective responses [215,216].

The prototype compound for this class of drugs is bryostatin 1.

Bryostatin 1 is a potent modulator of PKC activation [214,216,217]. In particular, short-term exposure with bryostatin 1 results in $\mathrm{cPKC}$ and $\mathrm{nPKC}$ activation and translocation to the nuclear membrane [218]. Conversely, prolonged exposure with bryostatin 1 results in membrane depletion of 
PKC and decreased PKC activity [219]. Due to bryostatin 1 showing significant growth-inhibitory activities against various cancer cell lines, its clinical application has been examined in phase I and II studies using a wide range of tumor types [220-223]. In phase I trials, bryostatin 1 showed anti-tumor activity, but phase II studies using bryostatin 1 alone were disappointing in melanoma [224], colorectal cancer [225] and gastric carcinoma [226]. The dose-limiting toxicity (DLT) in all studies was myalgia and localized phlebitis at the infusion site. Significant increases in plasma concentrations of TNF $\alpha$ and IL6, chosen as markers of PKC inhibitory activity, were observed when $50 \mu \mathrm{g}$ per $\mathrm{m}^{2}$ of bryostatin 1 was given as a weekly one hour infusion for three weeks out of four [223]. As the application of paclitaxel followed by bryostatin 1 significantly reduced tumor growth in mice [227], phase II studies of bryostatin 1, in combination with other cytotoxic agents, were tried in pancreatic and prostate cancer, and renal cell and gastric carcinoma [39,220,226]. In particular, an enhanced response to paclitaxel by bryostatin 1 was observed in advanced gastric or gastroesophageal junction adenocarcinoma [226] and in advanced esophageal and gastroesophageal junction cancer [228]. Recently, other combination (bryostatin 1 and vincristine) phase II study had efficacy in patients with aggressive B-cell non-Hodgkin lymphoma [229]. Moreover, these studies have emphasized the importance of the schedule sequence, the administration of bryostatin 1 before cisplatin, vincristine and gemcitabine being synergistic, while synergy with paclitaxel required the administration of bryostatin 1 after paclitaxel [227]. In addition, there is substantial evidence that bryostatin 1 is a potent immunostimulant $[230,231]$ suggesting that a single target of bryostatin 1 is not likely. In fact, an upregulation of IL2 by PKC has been reported and a phase II study was conducted combining IL2 with bryostatin 1 in patients with renal cell carcinoma. Although it was well tolerated, the addition of bryostatin 1 did not appear to improve response rates and there was no significant effect on T-cell expansion, activation or cytokine production [232]. Given that bryostatin has pleiotropic effects, it is not clear which are the most promising targets to measure in terms of predicting anticancer activity in any given tumor type. Currently there is no data on the predictive value of individual PKC isoenzymes in terms of bryostatin efficacy.

Ingenol-3-angelate (PEP005) is a novel compound extracted and purified from Euphorbia peplus. Chemically, PEP005 is structurally analogous to phorbol esters and is a potent modulator of PKC isoenzymes [233]. PEP005 was shown to modulate PKCs by activating PKC $\delta$ in human myeloid leukemia cancer cell lines, thereby inducing cellular apoptosis in melanoma [234] and in colon cancer models [235] through the inhibition of the AKT signaling pathway [236]. The antiproliferative effects of PEP005 were related to cell cycle inhibition in the G1 phase as well as the induction of apoptosis. Considering that concentrations required to observe cytotoxic effects, apoptosis, and/or cell cycle blockage may be limited by toxicity when PEP005 is given to patients with solid tumors, it is essential to evaluate combinations which could allow the use of lower concentrations of PEP005 and which might improve the cytotoxic effects of already used anticancer agents. This compound is currently in phase III clinical trials for the treatment of actinic keratosis [237] and phase II for non-melanoma skin cancer [238]. PEP005 exposure induced necrosis of tumor cells and caused a local moderate acute inflammatory response, which resolved over 5-10 days, leaving a favorable cosmetic effect [239]. It has been observed [235] that the action that PEP (4-1000 ng/mL) has on PKC is important for stimulating the observed inflammatory response [240], whereas, PKC activation is not required for inducing primary necrosis [239]. 
In addition, PEP005 emerges as a novel immunostimulatory chemotherapeutic agent that not only ablates the treated tumor, but in doing so also generates anti-cancer CD8 $\mathrm{T}$ cells that can synergize with CD8 T cell-based immunotherapies to regress distant secondary tumors [241]. However, only a limited number of reports of combination therapies have demonstrated that treatment of one tumor can lead to regression of distant pre-existing (secondary) tumors [242,243].

Curcumin is a natural polyphenol derived from the plant Curcuma longa, commonly called turmeric. This compound is a potent inhibitor of PKC [244] and acts by competing with calcium for the binding domain [245]. A number of preclinical studies showed that curcumin exhibits anti-tumor effects against a wide variety of cancers [244,246-250]. Several phase I and phase II clinical trials indicate that curcumin is quite safe and may exhibit therapeutic efficacy.

In particular, it has been demonstrated that a standardized formulation of curcuma extract could be efficacy in patients with advanced colorectal cancer [251]. Moreover, a study conducted in patients with familial adenomatous polyposis showed that curcumin could have a potential role in inhibiting this malignancy [252]. In addition, in a phase I clinical trial, a daily curcumin dose of $8000 \mathrm{mg}$ taken for three months resulted in histological improvement of precancerous lesions in patients having uterine cervical intraepithelial neoplasm, intestinal metaplasia, bladder cancer and oral leucoplakia [253].

Finally, clinical trials have demonstrated the efficacy of curcumin in patients with pancreatic cancer [254] and prostatic neoplasia [255].

Aprinocarsen (ISIS 3521) is an antisense oligonucleotide that induces a concentration-dependent reduction of $\mathrm{PKC} \alpha$ protein levels [256]. Continuous infusion of aprinocarsen was associated with greater uptake into tissues, prolonged inhibition of PKC $\alpha$ mRNA and reduced plasma concentrations. In phase I studies the main toxicities were fatigue, nausea, vomiting, fever and chills, and thrombocytopenia. Anti-tumor activity was shown in non-Hodgkin lymphoma and ovarian carcinoma in a phase I study [257], but no clinical benefit was observed in a phase II study in patients with recurrent high-grade astrocytomas [108] or with breast cancer. Phase I and II studies of aprinocarsen in combination with carboplatin and paclitaxel in NSCLC achieved a $42 \%$ response rate, suggesting potentiation of chemotherapy activity [258,259].

However, two randomized phase III studies in NSCLC failed to show a benefit from the addition of aprinocarsen to gemcitabine and cisplatin or to paclitaxel and carboplatin [260].

Nucleoside analogs, among them $A R C$ (NSC 188491, SMA-491), 4-amino-6-hydrazino-7- $\beta$-dribofuranosyl-7H-pyrrolo-(2,3-d)-pyrimidine-5-carboxamide and sangivamycin show in vitro a marked anti-cancer activity. This class of drug affects quiescent and proliferating cells by impacting DNA and RNA synthesis. Moreover, these two compounds are able to inhibit positive transcription elongation factor b (pTEFb), PKC and VEGF secretion [261]. The identical behavior of ARC and sangivamycin is interesting given that several reports exist of Phase I trials of sangivamycin in patients with a range of malignancies [262,263].

Perifosine octadecyl-(1,1-dimethyl-4-piperidylio) phosphate is a lipophilic orally bioavailable synthetic acetylphospholipid. It has shown antitumor activity in preclinical models. Although the exact mechanism of action is not yet fully understood, perifosine interacts with cell membranes and inhibits regulatory signal proteins including PKC [264]. This compound was the object of a phase I study and partial positive results were obtained in patients with chondrosarcoma and uterine sarcoma [265]. 
Disulfiram, Bis(N,N-(diethylthiocarbamoyl) disulfide (DSF), is an FDA-approved drug [266]. Its anticancer activity has been associated with S-thiolation and regulatory modulation of PKC isoenzymes [267]. Recently, it has been demonstrated that the redox active copper(II)-bis-N,N-diethyldithiocarbamate-derivative DSF was the causative agent underlying DSF-induced cancer cell apoptosis [266]. Recently, the potential role of DSF as a redox chemotherapeutic agent in metastatic melanoma has been reviewed [268,269]. The safety profile and prior clinical experience with DSF have encouraged ongoing clinical phase I and phase II studies in human metastatic melanoma (Clinical-Trials.gov Identifier: NCT00256230). A potential prooxidant potentiation that results in improved therapeutic benefit may exist between DSF and arsenic trioxide, a combination currently evaluated in patients with metastatic melanoma who underwent at least one prior systemic therapy (ClinicalTrials.gov Identifier: NCT00571116). Initial assessment of the effect of the addition of disulfiram to standard chemotherapy in NSCLC is the subject of an ongoing phase I trial (ClinicalTrials.gov Identifier: NCT00312819). Moreover, another phase I study examines disulfiram and copper gluconate for the treatment of refractory solid tumors involving the liver (ClinicalTrials.gov Identifier: NCT00742911).

\section{Conclusions}

PKC-dependent pathways participate in the resistance to chemotherapeutic treatments through the modulation of multi-drug transporters [98] and/or the regulation of apoptosis. Many studies have focused on rendering the chemotherapy more effective in order to overcome the evasion from apoptosis. In this regard, as we have reported, PKC isoform activation can be associated with chemoresistance but can also increase the sensitivity to chemotherapy (Figure 2). Moreover, emerging evidence also suggests that dysregulation of PKC isoenzymes is commonly observed in several malignancies and has been associated with promotion and propagation of cancer. For these reasons, PKC isoforms are attractive targets to kill cancer cells and increase the efficacy of chemotherapy. Natural compounds, small molecules and genetic approaches have been developed against PKCs, but the interpretation of clinical trials evaluating these approaches has been confusing and limited. The current PKC inhibitors clinically employed are relatively non-specific in their actions and, given the complexity of the functions and interactions of PKC isoenzymes, it is perhaps not surprising that agents targeting multiple isoenzymes give mixed results. Moreover, evidence from cell cultures and the early phases of clinical trials suggests promising results for the combination of conventional cytotoxic drugs with the current PKC inhibitors (Table 1). However, it is necessary to underly that the optimal combination and the sequence in which these drugs can be used needs to be carefully evaluated, bearing in mind that the efficacy of this strategy might be tumor type-dependent. Furthermore, additional translational research is needed to demonstrate if the modulation of "upstream-downstream" targets of PKC-dependent pathway might be more effective than either agent alone and if this approach will be beneficial in altering tumor progression. However, the therapeutic limitations of current drugs and the encouraging results of preclinical and clinical studies justify the continued search for drugs aimed at triggering the apoptotic response. 
Table 1. PKCs modulators and their clinical employment in human cancer.

\begin{tabular}{|c|c|c|}
\hline PKCs modulator & Tumor type & Ref. \\
\hline Midostaurin & $\begin{array}{l}\text { B-chronic lymphocytic leukemia } \\
\text { Acute myeloid leukemia } \\
\text { Malignant melanoma }\end{array}$ & $\begin{array}{l}{[182,183]} \\
{[184,185]} \\
{[186]}\end{array}$ \\
\hline Enzastaurin & $\begin{array}{l}\text { Lung cancer } \\
\text { Colorectal carcinoma } \\
\text { Renal carcinoma } \\
\text { High-grade gliomas } \\
\text { Diffuse large B-cell lymphoma }\end{array}$ & $\begin{array}{l}{[195]} \\
{[195]} \\
{[195]} \\
{[197]} \\
{[198,199]}\end{array}$ \\
\hline UCN-01 & $\begin{array}{l}\text { Leukemia } \\
\text { Non-small cell lung cancer } \\
\text { Lymphoma }\end{array}$ & $\begin{array}{l}\text { Under study } \\
\text { Under study } \\
\text { Under study }\end{array}$ \\
\hline Bryostatin 1 & $\begin{array}{l}\text { Gastric carcinoma } \\
\text { Adenocarcinoma } \\
\text { Esophageal and gastroesophageal cancer } \\
\text { Aggressive B-cell non-Hodgkin lymphoma }\end{array}$ & $\begin{array}{l}{[220]} \\
{[226]} \\
{[228]} \\
{[229]}\end{array}$ \\
\hline Ingenol-3-angelate & $\begin{array}{l}\text { Actinic keratosis } \\
\text { Non-melanoma skin cancer }\end{array}$ & $\begin{array}{l}{[237]} \\
{[238]}\end{array}$ \\
\hline Curcumin & $\begin{array}{l}\text { Advanced colorectal cancer } \\
\text { Familial adenomatous polyposis } \\
\text { Uterine cervical neoplasm } \\
\text { Intestinal metaplasia } \\
\text { Bladder cancer } \\
\text { Oral leukoplakia }\end{array}$ & $\begin{array}{l}{[251]} \\
{[252]} \\
{[253]} \\
{[253]} \\
{[253]} \\
{[253]}\end{array}$ \\
\hline Aprinocarsen & $\begin{array}{l}\text { Non-Hodgkin lymphoma } \\
\text { Ovarian carcinoma }\end{array}$ & $\begin{array}{l}{[257]} \\
{[257]}\end{array}$ \\
\hline $\begin{array}{l}\text { Perifosine octadecyl } \\
\text { phosphate }\end{array}$ & $\begin{array}{l}\text { Chondrosarcoma } \\
\text { Uterine sarcoma }\end{array}$ & $\begin{array}{l}{[265]} \\
{[265]}\end{array}$ \\
\hline Disulfiram & Metastatic melanoma & {$[268,269]$} \\
\hline
\end{tabular}


Figure 2. Schematic representation of the role of PKCs in cancer development and implication of their modulation in clinical therapy. PKC isoforms may act as tumor promoters or as tumor suppressors. Moreover, the activation of PKCs can be associated with resistance (increase in anti-apoptotic PKCs) but can also increase sensitivity (increase in pro-apoptotic PKCs) to chemotherapy.

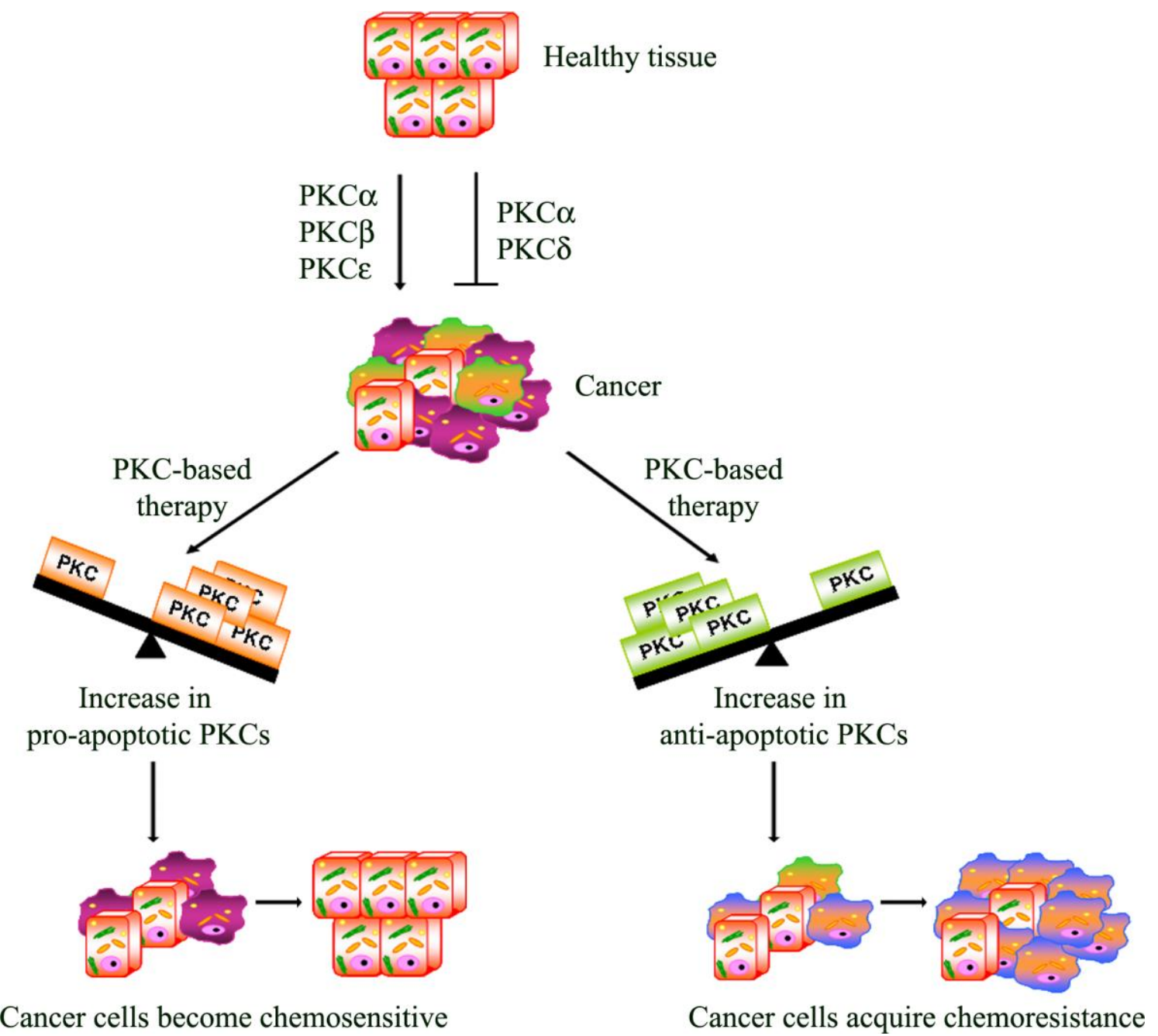

\section{Acknowledgments}

We thank Giuseppe Catalano (DIMES-University of Genoa) for his technical assistance and Suzanne Patten for English revision. This work was supported by grants from the Italian Ministry of Universities (PRIN n ${ }^{\circ}$ 2008N9N9KL_002) and Genoa University.

\section{References}

1. Takai, Y.; Kishimoto, A.; Inoue, M.; Nishizuka, Y. Studies on a cyclic nucleotide-independent protein kinase and its proenzyme in mammalian tissues. I. Purification and characterization of an active enzyme from bovine cerebellum. J. Biol. Chem. 1977, 252, 7603-7609.

2. Takai, Y.; Kishimoto, A.; Iwasa, Y.; Kawahara, Y.; Mori, T.; Nishizuka, Y. Calcium-dependent activation of a multifunctional protein kinase by membrane phospholipids. J. Biol. Chem. 1979, 254, 3692-3695. 
3. Newton, A.C. Protein kinase C: Structure, function, and regulation. J. Biol. Chem. 1995, 270, 28495-28498.

4. Nishizuka, Y. Intracellular signaling by hydrolysis of phospholipids and activation of protein kinase C. Science 1992, 258, 607-614.

5. Schenk, P.W.; Snaar-Jagalska, B.E. Signal perception and transduction: The role of protein kinases. Biochim. Biophys. Acta 1999, 1449, 1-24.

6. Newton, A.C. Regulation of the ABC kinases by phosphorylation: Protein kinase $\mathrm{C}$ as a paradigm. Biochem. J. 2003, 370, 361-371.

7. Parker, P.J.; Murray-Rust, J. PKC at a glance. J. Cell. Sci. 2004, 117, 131-132.

8. Blumberg, P.M.; Kedei, N.; Lewin, N.E.; Yang, D.; Czifra, G.; Pu, Y.; Peach, M.L.; Marquez, V.E. Wealth of opportunity - the $\mathrm{C} 1$ domain as a target for drug development. Curr. Drug Targets 2008, 9, 641-652.

9. Newton, A.C.; Johnson, J.E. Protein kinase C: A paradigm for regulation of protein function by two membrane-targeting modules. Biochim. Biophys. Acta 1998, 1376, 155-172.

10. Hurley, J.H. Membrane binding domains. Biochim. Biophys. Acta 2006, 1761, 805-811.

11. Sharkey, N.A.; Leach, K.L.; Blumberg, P.M. Competitive inhibition by diacylglycerol of specific phorbol ester binding. Proc. Natl. Acad. Sci. USA 1984, 81, 607-610.

12. Giorgione, J.R.; Lin, J.H.; McCammon, J.A.; Newton, A.C. Increased membrane affinity of the $\mathrm{C} 1$ domain of protein kinase Cdelta compensates for the lack of involvement of its $\mathrm{C} 2$ domain in membrane recruitment. J. Biol. Chem. 2006, 281, 1660-1669.

13. Lamark, T.; Perander, M.; Outzen, H.; Kristiansen, K.; Overvatn, A.; Michaelsen, E.; Bjorkoy, G.; Johansen, T. Interaction codes within the family of mammalian Phox and Bem1p domaincontaining proteins. J. Biol. Chem. 2003, 278, 34568-34581.

14. Moscat, J.; Diaz-Meco, M.T.; Albert, A.; Campuzano, S. Cell signaling and function organized by PB1 domain interactions. Mol. Cell. 2006, 23, 631-640.

15. Kishimoto, A.; Mikawa, K.; Hashimoto, K.; Yasuda, I.; Tanaka, S.; Tominaga, M.; Kuroda, T.; Nishizuka, Y. Limited proteolysis of protein kinase $\mathrm{C}$ subspecies by calcium-dependent neutral protease (calpain). J. Biol. Chem. 1989, 264, 4088-4092.

16. Parker, P.J.; Parkinson, S.J. AGC protein kinase phosphorylation and protein kinase C. Biochem. Soc. Trans. 2001, 29, 860-863.

17. Gould, C.M.; Kannan, N.; Taylor, S.S.; Newton, A.C. The chaperones Hsp90 and Cdc37 mediate the maturation and stabilization of protein kinase $\mathrm{C}$ through a conserved PXXP motif in the Cterminal tail. J. Biol. Chem. 2009, 284, 4921-4935.

18. Ikenoue, T.; Inoki, K.; Yang, Q.; Zhou, X.; Guan, K.L. Essential function of TORC2 in PKC and Akt turn motif phosphorylation, maturation and signalling. Embo J. 2008, 27, 1919-1931.

19. Leithe, E.; Cruciani, V.; Sanner, T.; Mikalsen, S.O.; Rivedal, E. Recovery of gap junctional intercellular communication after phorbol ester treatment requires proteasomal degradation of protein kinase C. Carcinogenesis 2003, 24, 1239-1245.

20. Brognard, J.; Newton, A.C. PHLiPPing the switch on Akt and protein kinase C signaling. Trends Endocrinol. Metab. 2008, 19, 223-230. 
21. Hansra, G.; Garcia-Paramio, P.; Prevostel, C.; Whelan, R.D.; Bornancin, F.; Parker, P.J. Multisite dephosphorylation and desensitization of conventional protein kinase $\mathrm{C}$ isotypes. Biochem. J. 1999, 342 (Pt. 2), 337-344.

22. Gopalakrishna, R.; Anderson, W.B. Ca2+- and phospholipid-independent activation of protein kinase $\mathrm{C}$ by selective oxidative modification of the regulatory domain. Proc. Natl. Acad. Sci. USA 1989, 86, 6758-6762.

23. Gopalakrishna, R.; Anderson, W.B. Susceptibility of protein kinase C to oxidative inactivation: Loss of both phosphotransferase activity and phorbol diester binding. FEBS Lett. 1987, 225, 233-237.

24. Gopalakrishna, R.; Jaken, S. Protein kinase C signaling and oxidative stress. Free Radic. Biol. Med. 2000, 28, 1349-1361.

25. Domenicotti, C.; Paola, D.; Vitali, A.; Nitti, M.; Cottalasso, D.; Melloni, E.; Poli, G.; Marinari, U.M.; Pronzato, M.A. Mechanisms of inactivation of hepatocyte protein kinase C isoforms following acute ethanol treatment. Free Radic. Biol. Med. 1998, 25, 529-535.

26. Ward, N.E.; Pierce, D.S.; Chung, S.E.; Gravitt, K.R.; O'Brian, C.A. Irreversible inactivation of protein kinase C by glutathione. J. Biol. Chem. 1998, 273, 12558-12566.

27. Mochly-Rosen, D.; Khaner, H.; Lopez, J. Identification of intracellular receptor proteins for activated protein kinase C. Proc. Natl. Acad. Sci. USA 1991, 88, 3997-4000.

28. Schechtman, D.; Mochly-Rosen, D. Adaptor proteins in protein kinase C-mediated signal transduction. Oncogene 2001, 20, 6339-6347.

29. Churchill, E.N.; Qvit, N.; Mochly-Rosen, D. Rationally designed peptide regulators of protein kinase C. Trends Endocrinol. Metab. 2009, 20, 25-33.

30. Maloney, J.A.; Tsygankova, O.; Szot, A.; Yang, L.; Li, Q.; Williamson, J.R. Differential translocation of protein kinase C isozymes by phorbol esters, EGF, and ANG II in rat liver WB cells. Am. J. Physiol. 1998, 274, C974-C982.

31. Wang, Q.J.; Bhattacharyya, D.; Garfield, S.; Nacro, K.; Marquez, V.E.; Blumberg, P.M. Differential localization of protein kinase $\mathrm{C}$ delta by phorbol esters and related compounds using a fusion protein with green fluorescent protein. J. Biol. Chem. 1999, 274, 37233-37239.

32. Kashiwagi, K.; Shirai, Y.; Kuriyama, M.; Sakai, N.; Saito, N. Importance of C1B domain for lipid messenger-induced targeting of protein kinase C. J. Biol. Chem. 2002, 277, 18037-18045.

33. Ohmori, T.; Arteaga, C.L. Protein kinase C epsilon translocation and phosphorylation by cisdiamminedichloroplatinum(II) (CDDP): Potential role in CDDP-mediated cytotoxicity. Cell Growth Differ. 1998, 9, 345-353.

34. Shirai, Y.; Kashiwagi, K.; Yagi, K.; Sakai, N.; Saito, N. Distinct effects of fatty acids on translocation of gamma- and epsilon-subspecies of protein kinase C. J. Cell. Biol. 1998, 143, 511-521.

35. Dempsey, E.C.; Newton, A.C.; Mochly-Rosen, D.; Fields, A.P.; Reyland, M.E.; Insel, P.A.; Messing, R.O. Protein kinase $\mathrm{C}$ isozymes and the regulation of diverse cell responses. Am. J. Physiol. Lung Cell. Mol. Physiol. 2000, 279, L429-L438.

36. Leitges, M. Functional PKC in vivo analysis using deficient mouse models. Biochem. Soc. Trans. 2007, 35, 1018-1020. 
37. Castagna, M.; Takai, Y.; Kaibuchi, K.; Sano, K.; Kikkawa, U.; Nishizuka, Y. Direct activation of calcium-activated, phospholipid-dependent protein kinase by tumor-promoting phorbol esters. $J$. Biol. Chem. 1982, 257, 7847-7851.

38. Kikkawa, U.; Takai, Y.; Tanaka, Y.; Miyake, R.; Nishizuka, Y. Protein kinase C as a possible receptor protein of tumor-promoting phorbol esters. J. Biol. Chem. 1983, 258, 11442-11445.

39. Mackay, H.J.; Twelves, C.J. Targeting the protein kinase C family: Are we there yet? Nat. Rev. Cancer 2007, 7, 554-562.

40. Mullin, J.M.; Laughlin, K.V.; Ginanni, N.; Marano, C.W.; Clarke, H.M.; Peralta Soler, A. Increased tight junction permeability can result from protein kinase $\mathrm{C}$ activation/translocation and act as a tumor promotional event in epithelial cancers. Ann. N. Y. Acad. Sci. 2000, 915, 231-236.

41. Song, J.C.; Rangachari, P.K.; Matthews, J.B. Opposing effects of PKCalpha and PKCepsilon on basolateral membrane dynamics in intestinal epithelia. Am. J. Physiol. Cell. Physiol. 2002, 283, C1548-C1556.

42. Konopatskaya, O.; Poole, A.W. Protein kinase Calpha: Disease regulator and therapeutic target. Trends Pharmacol. Sci. 2010, 31, 8-14.

43. Koren, R.; Ben Meir, D.; Langzam, L.; Dekel, Y.; Konichezky, M.; Baniel, J.; Livne, P.M.; Gal, R.; Sampson, S.R. Expression of protein kinase C isoenzymes in benign hyperplasia and carcinoma of prostate. Oncol. Rep. 2004, 11, 321-326.

44. Langzam, L.; Koren, R.; Gal, R.; Kugel, V.; Paz, A.; Farkas, A.; Sampson, S.R. Patterns of protein kinase $\mathrm{C}$ isoenzyme expression in transitional cell carcinoma of bladder. Relation to degree of malignancy. Am. J. Clin. Pathol. 2001, 116, 377-385.

45. Lahn, M.; Sundell, K.; Kohler, G. The role of protein kinase C-alpha in hematologic malignancies. Acta Haematol. 2006, 115, 1-8.

46. Neill, G.W.; Ghali, L.R.; Green, J.L.; Ikram, M.S.; Philpott, M.P.; Quinn, A.G. Loss of protein kinase Calpha expression may enhance the tumorigenic potential of Gli1 in basal cell carcinoma. Cancer Res. 2003, 63, 4692-4697.

47. Oster, H.; Leitges, M. Protein kinase C alpha but not PKCzeta suppresses intestinal tumor formation in ApcMin/+ mice. Cancer Res. 2006, 66, 6955-6963.

48. Lahn, M.; Kohler, G.; Sundell, K.; Su, C.; Li, S.; Paterson, B.M.; Bumol, T.F. Protein kinase C alpha expression in breast and ovarian cancer. Oncology 2004, 67, 1-10.

49. Tan, M.; Li, P.; Sun, M.; Yin, G.; Yu, D. Upregulation and activation of PKC alpha by ErbB2 through Src promotes breast cancer cell invasion that can be blocked by combined treatment with PKC alpha and Src inhibitors. Oncogene 2006, 25, 3286-3295.

50. Kerfoot, C.; Huang, W.; Rotenberg, S.A. Immunohistochemical analysis of advanced human breast carcinomas reveals downregulation of protein kinase $\mathrm{C}$ alpha. J. Histochem. Cytochem. 2004, 52, 419-422.

51. Lonne, G.K.; Cornmark, L.; Zahirovic, I.O.; Landberg, G.; Jirstrom, K.; Larsson, C. PKCalpha expression is a marker for breast cancer aggressiveness. Mol. Cancer 2010, 9, 76-89.

52. Wu, T.T.; Hsieh, Y.H.; Wu, C.C.; Hsieh, Y.S.; Huang, C.Y.; Liu, J.Y. Overexpression of protein kinase $\mathrm{C}$ alpha mRNA in human hepatocellular carcinoma: A potential marker of disease prognosis. Clin. Chim. Acta 2007, 382, 54-58. 
53. Hsieh, Y.H.; Wu, T.T.; Huang, C.Y.; Hsieh, Y.S.; Hwang, J.M.; Liu, J.Y. p38 mitogen-activated protein kinase pathway is involved in protein kinase Calpha-regulated invasion in human hepatocellular carcinoma cells. Cancer Res. 2007, 67, 4320-4327.

54. Leitges, M.; Schmedt, C.; Guinamard, R.; Davoust, J.; Schaal, S.; Stabel, S.; Tarakhovsky, A. Immunodeficiency in protein kinase cbeta-deficient mice. Science 1996, 273, 788-791.

55. Sledge, G.W., Jr.; Gokmen-Polar, Y. Protein kinase C-beta as a therapeutic target in breast cancer. Semin. Oncol. 2006, 33, S15-S18.

56. Suzuma, K.; Takahara, N.; Suzuma, I.; Isshiki, K.; Ueki, K.; Leitges, M.; Aiello, L.P.; King, G.L. Characterization of protein kinase $\mathrm{C}$ beta isoform's action on retinoblastoma protein phosphorylation, vascular endothelial growth factor-induced endothelial cell proliferation, and retinal neovascularization. Proc. Natl. Acad. Sci. USA 2002, 99, 721-726.

57. Gokmen-Polar, Y.; Murray, N.R.; Velasco, M.A.; Gatalica, Z.; Fields, A.P. Elevated protein kinase $\mathrm{C}$ betaII is an early promotive event in colon carcinogenesis. Cancer Res. 2001, 61, 1375-1381.

58. Yu, W.; Murray, N.R.; Weems, C.; Chen, L.; Guo, H.; Ethridge, R.; Ceci, J.D.; Evers, B.M.; Thompson, E.A.; Fields, A.P. Role of cyclooxygenase 2 in protein kinase C beta II-mediated colon carcinogenesis. J. Biol. Chem. 2003, 278, 11167-11174.

59. Zhang, J.; Anastasiadis, P.Z.; Liu, Y.; Thompson, E.A.; Fields, A.P. Protein kinase C (PKC) betaII induces cell invasion through a Ras/Mek-, PKC iota/Rac 1-dependent signaling pathway. $J$. Biol. Chem. 2004, 279, 22118-22123.

60. Graff, J.R.; McNulty, A.M.; Hanna, K.R.; Konicek, B.W.; Lynch, R.L.; Bailey, S.N.; Banks, C.; Capen, A.; Goode, R.; Lewis, J.E.; Sams, L.; Huss, K.L.; Campbell, R.M.; Iversen, P.W.; Neubauer, B.L.; Brown, T.J.; Musib, L.; Geeganage, S.; Thornton, D. The protein kinase Cbetaselective inhibitor, Enzastaurin (LY317615.HCl), suppresses signaling through the AKT pathway, induces apoptosis, and suppresses growth of human colon cancer and glioblastoma xenografts. Cancer Res. 2005, 65, 7462-7469.

61. Shipp, M.A.; Ross, K.N.; Tamayo, P.; Weng, A.P.; Kutok, J.L.; Aguiar, R.C.; Gaasenbeek, M.; Angelo, M.; Reich, M.; Pinkus, G.S.; Ray, T.S.; Koval, M.A.; Last, K.W.; Norton, A.; Lister, T.A.; Mesirov, J.; Neuberg, D.S.; Lander, E.S.; Aster, J.C.; Golub, T.R. Diffuse large B-cell lymphoma outcome prediction by gene-expression profiling and supervised machine learning. Nat. Med. 2002, 8, 68-74.

62. Krasagakis, K.; Fimmel, S.; Genten, D.; Eberle, J.; Quas, P.; Ziegler, W.; Haller, H.; Orfanos, C.E. Lack of protein kinase C (PKC)-beta and low PKC-alpha, -delta, -epsilon, and -zeta isozyme levels in proliferating human melanoma cells. Int. J. Oncol. 2002, 20, 865-871.

63. Saito, N.; Shirai, Y. Protein kinase C gamma (PKC gamma): Function of neuron specific isotype. J. Biochem. 2002, 132, 683-687.

64. Mazzoni, E.; Adam, A.; Bal de Kier Joffe, E.; Aguirre-Ghiso, J.A. Immortalized mammary epithelial cells overexpressing protein kinase $\mathrm{C}$ gamma acquire a malignant phenotype and become tumorigenic in vivo. Mol. Cancer Res. 2003, 1, 776-787.

65. Kamimura, K.; Hojo, H.; Abe, M. Characterization of expression of protein kinase C isozymes in human B-cell lymphoma: Relationship between its expression and prognosis. Pathol. Int. 2004, $54,224-230$. 
66. Kajimoto, T.; Shirai, Y.; Sakai, N.; Yamamoto, T.; Matsuzaki, H.; Kikkawa, U.; Saito, N. Ceramide-induced apoptosis by translocation, phosphorylation, and activation of protein kinase Cdelta in the Golgi complex. J. Biol. Chem. 2004, 279, 12668-12676.

67. Reyland, M.E.; Anderson, S.M.; Matassa, A.A.; Barzen, K.A.; Quissell, D.O. Protein kinase C delta is essential for etoposide-induced apoptosis in salivary gland acinar cells. J. Biol. Chem. 1999, 274, 19115-19123.

68. Majumder, P.K.; Mishra, N.C.; Sun, X.; Bharti, A.; Kharbanda, S.; Saxena, S.; Kufe, D. Targeting of protein kinase $\mathrm{C}$ delta to mitochondria in the oxidative stress response. Cell. Growth Differ. 2001, 12, 465-470.

69. Domenicotti, C.; Marengo, B.; Verzola, D.; Garibotto, G.; Traverso, N.; Patriarca, S.; Maloberti, G.; Cottalasso, D.; Poli, G.; Passalacqua, M.; Melloni, E.; Pronzato, M.A.; Marinari, U.M. Role of PKC-delta activity in glutathione-depleted neuroblastoma cells. Free Radic. Biol. Med. 2003, 35 , 504-516.

70. Jackson, D.N.; Foster, D.A. The enigmatic protein kinase Cdelta: Complex roles in cell proliferation and survival. Faseb J. 2004, 18, 627-636.

71. Lu, Z.; Hornia, A.; Jiang, Y.W.; Zang, Q.; Ohno, S.; Foster, D.A. Tumor promotion by depleting cells of protein kinase C delta. Mol. Cell. Biol. 1997, 17, 3418-3428.

72. Riobo, N.A.; Haines, G.M.; Emerson, C.P., Jr. Protein kinase C-delta and mitogen-activated protein/extracellular signal-regulated kinase-1 control GLI activation in hedgehog signaling. Cancer Res. 2006, 66, 839-845.

73. Griner, E.M.; Kazanietz, M.G. Protein kinase C and other diacylglycerol effectors in cancer. Nat. Rev. Cancer 2007, 7, 281-294.

74. Reno, E.M.; Haughian, J.M.; Dimitrova, I.K.; Jackson, T.A.; Shroyer, K.R.; Bradford, A.P. Analysis of protein kinase $\mathrm{C}$ delta (PKC delta) expression in endometrial tumors. Hum. Pathol. 2008, 39, 21-29.

75. McKiernan, E.; O'Brien, K.; Grebenchtchikov, N.; Geurts-Moespot, A.; Sieuwerts, A.M.; Martens, J.W.; Magdolen, V.; Evoy, D.; McDermott, E.; Crown, J.; Sweep, F.C.; Duffy, M.J. Protein kinase Cdelta expression in breast cancer as measured by real-time PCR, western blotting and ELISA. Br. J. Cancer 2008, 99, 1644-1650.

76. Nabha, S.M.; Glaros, S.; Hong, M.; Lykkesfeldt, A.E.; Schiff, R.; Osborne, K.; Reddy, K.B. Upregulation of PKC-delta contributes to antiestrogen resistance in mammary tumor cells. Oncogene 2005, 24, 3166-3176.

77. Gonzalez-Guerrico, A.M.; Kazanietz, M.G. Phorbol ester-induced apoptosis in prostate cancer cells via autocrine activation of the extrinsic apoptotic cascade: A key role for protein kinase C delta. J. Biol. Chem. 2005, 280, 38982-38991.

78. Gavrielides, M.V.; Gonzalez-Guerrico, A.M.; Riobo, N.A.; Kazanietz, M.G. Androgens regulate protein kinase Cdelta transcription and modulate its apoptotic function in prostate cancer cells. Cancer Res. 2006, 66, 11792-11801.

79. Yadav, V.; Yanez, N.C.; Fenton, S.E.; Denning, M.F. Loss of protein kinase C delta gene expression in human squamous cell carcinomas: A laser capture microdissection study. Am. J. Pathol. 2010, 176, 1091-1096. 
80. Mauro, L.V.; Grossoni, V.C.; Urtreger, A.J.; Yang, C.; Colombo, L.L.; Morandi, A.; Pallotta, M.G.; Kazanietz, M.G.; Bal de Kier Joffé, E.D.; Puricelli, L.L. PKC Delta (PKCdelta) promotes tumoral progression of human ductal pancreatic cancer. Pancreas 2010, 39, 31-41.

81. Ozpolat, B.; Akar, U.; Mehta, K.; Lopez-Berestein, G. PKC delta and tissue transglutaminase are novel inhibitors of autophagy in pancreatic cancer cells. Autophagy 2007, 3, 480-483.

82. Cacace, A.M.; Guadagno, S.N.; Krauss, R.S.; Fabbro, D.; Weinstein, I.B. The epsilon isoform of protein kinase $\mathrm{C}$ is an oncogene when overexpressed in rat fibroblasts. Oncogene 1993, 8, 2095-2104.

83. Baxter, G.; Oto, E.; Daniel-Issakani, S.; Strulovici, B. Constitutive presence of a catalytic fragment of protein kinase $\mathrm{C}$ epsilon in a small cell lung carcinoma cell line. J. Biol. Chem. 1992, 267, 1910-1917.

84. Mischak, H.; Goodnight, J.A.; Kolch, W.; Martiny-Baron, G.; Schaechtle, C.; Kazanietz, M.G.; Blumberg, P.M.; Pierce, J.H.; Mushinski, J.F. Overexpression of protein kinase C-delta and epsilon in NIH 3T3 cells induces opposite effects on growth, morphology, anchorage dependence, and tumorigenicity. J. Biol. Chem. 1993, 268, 6090-6096.

85. Perletti, G.P.; Folini, M.; Lin, H.C.; Mischak, H.; Piccinini, F.; Tashjian, A.H.Jr. Overexpression of protein kinase $\mathrm{C}$ epsilon is oncogenic in rat colonic epithelial cells. Oncogene 1996, 12, 847-854.

86. Pan, Q.; Bao, L.W.; Kleer, C.G.; Sabel, M.S.; Griffith, K.A.; Teknos, T.N.; Merajver, S.D. Protein kinase $\mathrm{C}$ epsilon is a predictive biomarker of aggressive breast cancer and a validated target for RNA interference anticancer therapy. Cancer Res. 2005, 65, 8366-8371.

87. Verma, A.K.; Wheeler, D.L.; Aziz, M.H.; Manoharan, H. Protein kinase Cepsilon and development of squamous cell carcinoma, the nonmelanoma human skin cancer. Mol. Carcinog. 2006, 45, 381-388.

88. Sharif, T.R.; Sharif, M. Overexpression of protein kinase C epsilon in astroglial brain tumor derived cell lines and primary tumor samples. Int. J. Oncol. 1999, 15, 237-243.

89. Sharif, T.R.; Sasakawa, N.; Sharif, M. Regulated expression of a dominant negative protein kinase $\mathrm{C}$ epsilon mutant inhibits the proliferation of U-373MG human astrocytoma cells. Int. J. Mol. Med. 2001, 7, 373-380.

90. Engers, R.; Mrzyk, S.; Springer, E.; Fabbro, D.; Weissgerber, G.; Gernharz, C.D.; Gabbert, H.E. Protein kinase $\mathrm{C}$ in human renal cell carcinomas: Role in invasion and differential isoenzyme expression. Br. J. Cancer 2000, 82, 1063-1069.

91. Pan, Q.; Bao, L.W.; Teknos, T.N.; Merajver, S.D. Targeted disruption of protein kinase C epsilon reduces cell invasion and motility through inactivation of RhoA and RhoC GTPases in head and neck squamous cell carcinoma. Cancer Res. 2006, 66, 9379-9384.

92. Hernandez, R.M.; Wescott, G.G.; Mayhew, M.W.; McJilton, M.A.; Terrian, D.M. Biochemical and morphogenic effects of the interaction between protein kinase C-epsilon and actin in vitro and in cultured NIH3T3 cells. J. Cell. Biochem. 2001, 83, 532-546.

93. Zhang, J.; Baines, C.P.; Zong, C.; Cardwell, E.M.; Wang, G.; Vondriska, T.M.; Ping, P. Functional proteomic analysis of a three-tier PKCepsilon-Akt-eNOS signaling module in cardiac protection. Am. J. Physiol. Heart Circ. Physiol. 2005, 288, H954-H961. 
94. Aziz, M.H.; Manoharan, H.T.; Church, D.R.; Dreckschmidt, N.E.; Zhong, W.; Oberley, T.D.; Wilding, G.; Verma, A.K. Protein kinase Cepsilon interacts with signal transducers and activators of transcription 3 (Stat3), phosphorylates Stat3Ser727, and regulates its constitutive activation in prostate cancer. Cancer Res. 2007, 67, 8828-8838.

95. Wu, D.; Foreman, T.L.; Gregory, C.W.; McJilton, M.A.; Wescott, G.G.; Ford, O.H.; Alvey, R.F.; Mohler, J.L.; Terrian, D.M. Protein kinase cepsilon has the potential to advance the recurrence of human prostate cancer. Cancer Res. 2002, 62, 2423-2429.

96. Knauf, J.A.; Elisei, R.; Mochly-Rosen, D.; Liron, T.; Chen, X.N.; Gonsky, R.; Korenberg, J.R.; Fagin, J.A. Involvement of protein kinase Cepsilon (PKCepsilon) in thyroid cell death. A truncated chimeric PKCepsilon cloned from a thyroid cancer cell line protects thyroid cells from apoptosis. J. Biol. Chem. 1999, 274, 23414-23425.

97. Gorin, M.A.; Pan, Q. Protein kinase C epsilon: An oncogene and emerging tumor biomarker. Mol. Cancer 2009, 8, 9.

98. Fine, R.L.; Patel, J.; Chabner, B.A. Phorbol esters induce multidrug resistance in human breast cancer cells. Proc. Natl. Acad. Sci. USA 1988, 85, 582-586.

99. Haimovitz-Friedman, A.; Balaban, N.; McLoughlin, M.; Ehleiter, D.; Michaeli, J.; Vlodavsky, I.; Fuks, Z. Protein kinase $\mathrm{C}$ mediates basic fibroblast growth factor protection of endothelial cells against radiation-induced apoptosis. Cancer Res. 1994, 54, 2591-2597.

100. Ahmad, S.; Mineta, T.; Martuza, R.L.; Glazer, R.I. Antisense expression of protein kinase C alpha inhibits the growth and tumorigenicity of human glioblastoma cells. Neurosurgery 1994, 35, 904-908; discussion 908-909.

101. Dooley, N.P.; Baltuch, G.H.; Groome, N.; Villemure, J.G.; Yong, V.W. Apoptosis is induced in glioma cells by antisense oligonucleotides to protein kinase $\mathrm{C}$ alpha and is enhanced by cycloheximide. Neuroreport 1998, 9, 1727-1733.

102. Meinhardt, G.; Roth, J.; Hass, R. Activation of protein kinase $\mathrm{C}$ relays distinct signaling pathways in the same cell type: Differentiation and caspase-mediated apoptosis. Cell Death Differ. 2000, 7, 795-803.

103. Ruvolo, P.P.; Deng, X.; Carr, B.K.; May, W.S. A functional role for mitochondrial protein kinase Calpha in Bcl2 phosphorylation and suppression of apoptosis. J. Biol. Chem. 1998, 273, 25436-25442.

104. Majewski, M.; Nieborowska-Skorska, M.; Salomoni, P.; Slupianek, A.; Reiss, K.; Trotta, R.; Calabretta, B.; Skorski, T. Activation of mitochondrial Raf-1 is involved in the antiapoptotic effects of Akt. Cancer Res. 1999, 59, 2815-2819.

105. Mandil, R.; Ashkenazi, E.; Blass, M.; Kronfeld, I.; Kazimirsky, G.; Rosenthal, G.; Umansky, F.; Lorenzo, P.S.; Blumberg, P.M.; Brodie, C. Protein kinase Calpha and protein kinase Cdelta play opposite roles in the proliferation and apoptosis of glioma cells. Cancer Res. 2001, 61, 4612-4619.

106. Jiffar, T.; Kurinna, S.; Suck, G.; Carlson-Bremer, D.; Ricciardi, M.R.; Konopleva, M.; Andreeff, M.; Ruvolo, P.P. PKC alpha mediates chemoresistance in acute lymphoblastic leukemia through effects on Bcl2 phosphorylation. Leukemia 2004, 18, 505-512.

107. Wang, X.Y.; Repasky, E.; Liu, H.T. Antisense inhibition of protein kinase Calpha reverses the transformed phenotype in human lung carcinoma cells. Exp. Cell Res. 1999, 250, 253-263. 
108. Grossman, S.A.; Alavi, J.B.; Supko, J.G.; Carson, K.A.; Priet, R.; Dorr, F.A.; Grundy, J.S.; Holmlund, J.T. Efficacy and toxicity of the antisense oligonucleotide aprinocarsen directed against protein kinase $\mathrm{C}$-alpha delivered as a 21-day continuous intravenous infusion in patients with recurrent high-grade astrocytomas. Neuro Oncol. 2005, 7, 32-40.

109. Leli, U.; Parker, P.J.; Shea, T.B. Intracellular delivery of protein kinase C-alpha or -epsilon isoform-specific antibodies promotes acquisition of a morphologically differentiated phenotype in neuroblastoma cells. FEBS Lett. 1992, 297, 91-94.

110. Haughian, J.M.; Reno, E.M.; Thorne, A.M.; Bradford, A.P. Protein kinase C alpha-dependent signaling mediates endometrial cancer cell growth and tumorigenesis. Int. J. Cancer 2009, 125, 2556-2564.

111. Powell, C.T.; Brittis, N.J.; Stec, D.; Hug, H.; Heston, W.D.; Fair, W.R. Persistent membrane translocation of protein kinase $\mathrm{C}$ alpha during 12-0-tetradecanoylphorbol-13-acetate-induced apoptosis of LNCaP human prostate cancer cells. Cell Growth Differ. 1996, 7, 419-428.

112. Nowak, G. Protein kinase C-alpha and ERK1/2 mediate mitochondrial dysfunction, decreases in active $\mathrm{Na}+$ transport, and cisplatin-induced apoptosis in renal cells. J. Biol. Chem. 2002, 277, 43377-43388.

113. Detjen, K.M.; Brembeck, F.H.; Welzel, M.; Kaiser, A.; Haller, H.; Wiedenmann, B.; Rosewicz, S. Activation of protein kinase Calpha inhibits growth of pancreatic cancer cells via p21(cip)mediated G(1) arrest. J. Cell Sci. 2000, 113 (Pt. 17), 3025-3035.

114. Slosberg, E.D.; Klein, M.G.; Yao, Y.; Han, E.K.; Schieren, I.; Weinstein, I.B. The alpha isoform of protein kinase $\mathrm{C}$ mediates phorbol ester-induced growth inhibition and $\mathrm{p} 21 \mathrm{cip} 1$ induction in HC11 mammary epithelial cells. Oncogene 1999, 18, 6658-6666.

115. Frey, M.R.; Saxon, M.L.; Zhao, X.; Rollins, A.; Evans, S.S.; Black, J.D. Protein kinase C isozyme-mediated cell cycle arrest involves induction of p21(waf1/cip1) and p27(kip1) and hypophosphorylation of the retinoblastoma protein in intestinal epithelial cells. J. Biol. Chem. 1997, 272, 9424-9435.

116. Clark, J.A.; Black, A.R.; Leontieva, O.V.; Frey, M.R.; Pysz, M.A.; Kunneva, L.; WoloszynskaRead, A.; Roy, D.; Black, J.D. Involvement of the ERK signaling cascade in protein kinase Cmediated cell cycle arrest in intestinal epithelial cells. J. Biol. Chem. 2004, 279, 9233-9247.

117. Orlandi, L.; Binda, M.; Folini, M.; Bearzatto, A.; Villa, R.; Daidone, M.G.; Zaffaroni, N. Ribozyme-mediated inhibition of PKCalpha sensitizes androgen-independent human prostate cancer cells to cisplatin-induced apoptosis. Prostate 2003, 54, 133-143.

118. Tonetti, D.A.; Morrow, M.; Kidwai, N.; Gupta, A.; Badve, S. Elevated protein kinase C alpha expression may be predictive of tamoxifen treatment failure.Br. J. Cancer 2003, 88, 1400-1402.

119. Ono, Y.; Kikkawa, U.; Ogita, K.; Fujii, T.; Kurokawa, T.; Asaoka, Y.; Sekiguchi, K.; Ase, K.; Igarashi, K.; Nishizuka, Y. Expression and properties of two types of protein kinase C: Alternative splicing from a single gene. Science 1987, 236, 1116-1120.

120. Deacon, E.M.; Pongracz, J.; Griffiths, G.; Lord, J.M. Isoenzymes of protein kinase C: Differential involvement in apoptosis and pathogenesis. Mol. Pathol. 1997, 50, 124-131.

121. Murray, N.R.; Baumgardner, G.P.; Burns, D.J.; Fields, A.P. Protein kinase C isotypes in human erythroleukemia (K562) cell proliferation and differentiation. Evidence that beta II protein kinase C is required for proliferation. J. Biol. Chem. 1993, 268, 15847-15853. 
122. Sauma, S.; Yan, Z.; Ohno, S.; Friedman, E. Protein kinase C beta 1 and protein kinase C beta 2 activate p57 mitogen-activated protein kinase and block differentiation in colon carcinoma cells. Cell Growth Differ. 1996, 7, 587-594.

123. Svensson, K.; Zeidman, R.; Troller, U.; Schultz, A.; Larsson, C. Protein kinase C beta1 is implicated in the regulation of neuroblastoma cell growth and proliferation. Cell Growth Differ. 2000, 11, 641-648.

124. Murray, N.R.; Weems, C.; Chen, L.; Leon, J.; Yu, W.; Davidson, L.A.; Jamieson, L.; Chapkin, R.S.; Thompson, E.A.; Fields, A.P. Protein kinase $\mathrm{C}$ betaII and TGFbetaRII in omega-3 fatty acid-mediated inhibition of colon carcinogenesis. J. Cell. Biol. 2002, 157, 915-920.

125.Zhu, G.H.; Wong, B.C.; Slosberg, E.D.; Eggo, M.C.; Ching, C.K.; Yuen, S.T.; Lai, K.C.; Soh, J.W.; Weinstein, I.B.; Lam, S.K. Overexpression of protein kinase C-beta1 isoenzyme suppresses indomethacin-induced apoptosis in gastric epithelial cells. Gastroenterology 2000, 118, 507-514.

126. Jiang, X.H.; Lam, S.K.; Lin, M.C.; Jiang, S.H.; Kung, H.F.; Slosberg, E.D.; Soh, J.W.; Weinstein, I.B.; Wong, B.C. Novel target for induction of apoptosis by cyclo-oxygenase-2 inhibitor SC-236 through a protein kinase C-beta(1)-dependent pathway. Oncogene 2002, 21, 6113-6122.

127. Evans, C.A.; Lord, J.M.; Owen-Lynch, P.J.; Johnson, G.; Dive, C.; Whetton, A.D. Suppression of apoptosis by $\mathrm{v}-\mathrm{ABL}$ protein tyrosine kinase is associated with nuclear translocation and activation of protein kinase C in an interleukin-3-dependent haemopoietic cell line. J. Cell. Sci. 1995, 108 (Pt. 7), 2591-2598.

128. Goss, V.L.; Hocevar, B.A.; Thompson, L.J.; Stratton, C.A.; Burns, D.J.; Fields, A.P. Identification of nuclear beta II protein kinase $\mathrm{C}$ as a mitotic lamin kinase. J. Biol. Chem. 1994, 269, 19074-19080.

129. Chiarini, A.; Whitfield, J.F.; Armato, U.; Dal Pra, I. Protein kinase C-beta II Is an apoptotic lamin kinase in polyomavirus-transformed, etoposide-treated pyF111 rat fibroblasts. J. Biol. Chem. 2002, 277, 18827-18839.

130. Hocevar, B.A; Fields, A.P. Selective translocation of beta II-protein kinase C to the nucleus of human promyelocytic (HL60) leukemia cells. J. Biol. Chem. 1991, 266, 28-33.

131. Macfarlane, D.E.; Manzel, L. Activation of beta-isozyme of protein kinase C (PKC beta) is necessary and sufficient for phorbol ester-induced differentiation of HL-60 promyelocytes. Studies with PKC beta-defective PET mutant. J. Biol. Chem. 1994, 269, 4327-4331.

132. Ito, Y.; Mishra, N.C.; Yoshida, K.; Kharbanda, S.; Saxena, S.; Kufe, D. Mitochondrial targeting of JNK/SAPK in the phorbol ester response of myeloid leukemia cells. Cell Death Differ. 2001, 8, 794-800.

133. Watanabe, T.; Ono, Y.; Taniyama, Y.; Hazama, K.; Igarashi, K.; Ogita, K.; Kikkawa, U.; Nishizuka, Y. Cell division arrest induced by phorbol ester in $\mathrm{CHO}$ cells overexpressing protein kinase C-delta subspecies. Proc. Natl. Acad. Sci. USA 1992, 89, 10159-10163.

134. Domenicotti, C.; Marengo, B.; Nitti, M.; Verzola, D.; Garibotto, G.; Cottalasso, D.; Poli, G.; Melloni, E.; Pronzato, M.A.: Marinari, U.M. A novel role of protein kinase C-delta in cell signaling triggered by glutathione depletion. Biochem. Pharmacol. 2003, 66, 1521-1526.

135. Khwaja, A.; Tatton, L. Caspase-mediated proteolysis and activation of protein kinase Cdelta plays a central role in neutrophil apoptosis. Blood 1999, 94, 291-301. 
136. Matassa, A.A.; Carpenter, L.; Biden, T.J.; Humphries, M.J.; Reyland, M.E. PKCdelta is required for mitochondrial-dependent apoptosis in salivary epithelial cells. J. Biol. Chem. 2001, 276, 29719-29728.

137. DeVries, T.A.; Neville, M.C.; Reyland, M.E. Nuclear import of PKCdelta is required for apoptosis: Identification of a novel nuclear import sequence. Embo J. 2002, 21, 6050-6060.

138. Basu, A.; Woolard, M.D.; Johnson, C.L. Involvement of protein kinase C-delta in DNA damageinduced apoptosis. Cell Death Differ. 2001, 8, 899-908.

139. Brodie, C.; Blumberg, P.M. Regulation of cell apoptosis by protein kinase c delta. Apoptosis 2003, 8, 19-27.

140. Cross, T.; Griffiths, G.; Deacon, E.; Sallis, R.; Gough, M.; Watters, D.; Lord, J.M. PKC-delta is an apoptotic lamin kinase. Oncogene 2000, 19, 2331-2337.

141. Yoshida, K.; Wang, H.G.; Miki, Y.; Kufe, D. Protein kinase Cdelta is responsible for constitutive and DNA damage-induced phosphorylation of Rad9. Embo J. 2003, 22, 1431-1441.

142. DeVries, T.A.; Kalkofen, R.L.; Matassa, A.A.; Reyland, M.E. Protein kinase Cdelta regulates apoptosis via activation of STAT1. J. Biol. Chem. 2004, 279, 45603-45612.

143. Ren, J.; Datta, R.; Shioya, H.; Li, Y.; Oki, E.; Biedermann, V.; Bharti, A.; Kufe, D. p73beta is regulated by protein kinase Cdelta catalytic fragment generated in the apoptotic response to DNA damage. J. Biol. Chem. 2002, 277, 33758-33765.

144. Abbas, T.; White, D.; Hui, L.; Yoshida, K.; Foster, D.A.; Bargonetti, J. Inhibition of human p53 basal transcription by down-regulation of protein kinase Cdelta. J. Biol. Chem. 2004, 279, 9970-9977.

145. Liu, H.; Lu, Z.G.; Miki, Y.; Yoshida, K. Protein kinase C delta induces transcription of the TP53 tumor suppressor gene by controlling death-promoting factor Btf in the apoptotic response to DNA damage. Mol. Cell. Biol. 2007, 27, 8480-8491.

146. Ryer, E.J.; Sakakibara, K.; Wang, C.; Sarkar, D.; Fisher, P.B.; Faries, P.L.; Kent, K.C.; Liu, B. Protein kinase $\mathrm{C}$ delta induces apoptosis of vascular smooth muscle cells through induction of the tumor suppressor p53 by both p38-dependent and p38-independent mechanisms. J. Biol. Chem. 2005, 280, 35310-35317.

147. Lee, S.J.; Kim, D.C.; Choi, B.H.; Ha, H.; Kim, K.T. Regulation of p53 by activated protein kinase C-delta during nitric oxide-induced dopaminergic cell death. J. Biol. Chem. 2006, 281, 2215-2224.

148. Yoshida, K.; Miki, Y.; Kufe, D. Activation of SAPK/JNK signaling by protein kinase Cdelta in response to DNA damage. J. Biol. Chem. 2002, 277, 48372-48378.

149. Yuan, Z.M.; Utsugisawa, T.; Ishiko, T.; Nakada, S.; Huang, Y.; Kharbanda, S.; Weichselbaum, R.; Kufe, D. Activation of protein kinase $\mathrm{C}$ delta by the c-Abl tyrosine kinase in response to ionizing radiation. Oncogene 1998, 16, 1643-1648.

150. Suh, K.S.; Tatunchak, T.T.; Crutchley, J.M.; Edwards, L.E.; Marin, K.G.; Yuspa, S.H. Genomic structure and promoter analysis of PKC-delta. Genomics 2003, 82, 57-67.

151. Konishi, H.; Yamauchi, E.; Taniguchi, H.; Yamamoto, T.; Matsuzaki, H.; Takemura, Y.; Ohmae, K.; Kikkawa, U.; Nishizuka, Y. Phosphorylation sites of protein kinase C delta in $\mathrm{H} 2 \mathrm{O} 2$-treated cells and its activation by tyrosine kinase in vitro. Proc. Natl. Acad. Sci. USA 2001, 98, 6587-6592. 
152. Reyland, M.E. Protein kinase Cdelta and apoptosis. Biochem. Soc. Trans. 2007, 35, 1001-1004.

153. Jun, C.D.; Oh, C.D.; Kwak, H.J.; Pae, H.O.; Yoo, J.C.; Choi, B.M.; Chun, J.S.; Park, R.K.; Chung, H.T. Overexpression of protein kinase C isoforms protects RAW 264.7 macrophages from nitric oxide-induced apoptosis: Involvement of c-Jun N-terminal kinase/stress-activated protein kinase, p38 kinase, and CPP-32 protease pathways. J. Immunol. 1999, 162, 3395-3401.

154. Okhrimenko, H.; Lu, W.; Xiang, C.; Ju, D.; Blumberg, P.M.; Gomel, R.; Kazimirsky, G.; Brodie, C. Roles of tyrosine phosphorylation and cleavage of protein kinase Cdelta in its protective effect against tumor necrosis factor-related apoptosis inducing ligand-induced apoptosis. J. Biol. Chem. 2005, 280, 23643-23652.

155. Kajimoto, T.; Ohmori, S.; Shirai, Y.; Sakai, N.; Saito, N. Subtype-specific translocation of the delta subtype of protein kinase $\mathrm{C}$ and its activation by tyrosine phosphorylation induced by ceramide in HeLa cells. Mol. Cell Biol. 2001, 21, 1769-1783.

156. Thomenius, M.J.; Wang, N.S.; Reineks, E.Z.; Wang, Z.; Distelhorst, C.W. Bcl-2 on the endoplasmic reticulum regulates Bax activity by binding to BH3-only proteins. J. Biol. Chem. 2003, 278, 6243-6250.

157. Lee, Y.J.; Lee, D.H.; Cho, C.K.; Bae, S.; Jhon, G.J.; Lee, S.J.; Soh, J.W.; Lee, Y.S. HSP25 inhibits protein kinase $\mathrm{C}$ delta-mediated cell death through direct interaction. J. Biol. Chem. 2005, 280, 18108-18119.

158. Jiang, K.; Apostolatos, A.H.; Ghansah, T.; Watson, J.E.; Vickers, T.; Cooper, D.R.; EplingBurnette, P.K.; Patel, N.A. Identification of a novel antiapoptotic human protein kinase C delta isoform, PKCdeltaVIII in NT2 cells. Biochemistry 2008, 47, 787-797.

159. Lu, D.; Sivaprasad, U.; Huang, J.; Shankar, E.; Morrow, S.; Basu, A. Protein kinase C-epsilon protects MCF-7 cells from TNF-mediated cell death by inhibiting Bax translocation. Apoptosis 2007, 12, 1893-1900.

160. Basu, A.; Lu, D.; Sun, B.; Moor, A.N.; Akkaraju, G.R.; Huang, J. Proteolytic activation of protein kinase C-epsilon by caspase-mediated processing and transduction of antiapoptotic signals. $J$. Biol. Chem. 2002, 277, 41850-41856.

161. Castrillo, A.; Pennington, D.J.; Otto, F.; Parker, P.J.; Owen, M.J.; Bosca, L. Protein kinase Cepsilon is required for macrophage activation and defense against bacterial infection. $J$. Exp. Med. 2001, 194, 1231-1242.

162. Sivaprasad, U.; Shankar, E.; Basu, A. Downregulation of Bid is associated with PKCepsilonmediated TRAIL resistance. Cell Death Differ. 2007, 14, 851-860.

163. Shinohara, H.; Kayagaki, N.; Yagita, H.; Oyaizu, N.; Ohba, M.; Kuroki, T.; Ikawa, Y. A protective role of PKCepsilon against TNF-related apoptosis-inducing ligand (TRAIL)-induced apoptosis in glioma cells. Biochem. Biophys. Res. Commun. 2001, 284, 1162-1167.

164. Wu, D.; Thakore, C.U.; Wescott, G.G.; McCubrey, J.A.; Terrian, D.M. Integrin signaling links protein kinase Cepsilon to the protein kinase B/Akt survival pathway in recurrent prostate cancer cells. Oncogene 2004, 23, 8659-8672.

165. Basu, A.; Sivaprasad, U. Protein kinase Cepsilon makes the life and death decision. Cell Signal. 2007, 19, 1633-1642.

166. Wen, H.C.; Huang, W.C.; Ali, A.; Woodgett, J.R.; Lin, W.W. Negative regulation of phosphatidylinositol 3-kinase and Akt signalling pathway by PKC. Cell Signal. 2003, 15, 37-45. 
167. Suzuki, A.; Goto, Y.; Iguchi, T. Progression of PDMT is accompanied by lack of Fas and intense expression of Bcl-2 and PKC-epsilon. Carcinogenesis 1997, 18, 883-887.

168. McJilton, M.A.; Van Sikes, C.; Wescott, G.G.; Wu, D.; Foreman, T.L.; Gregory, C.W.; Weidner, D.A.; Harris Ford, O.; Morgan Lasater, A.; Mohler, J.L.; Terrian, D.M. Protein kinase Cepsilon interacts with Bax and promotes survival of human prostate cancer cells. Oncogene 2003, 22, 7958-7968.

169. Pardo, O.E.; Wellbrock, C.; Khanzada, U.K.; Aubert, M.; Arozarena, I.; Davidson, S.; Bowen, F.; Parker, P.J.; Filonenko, V.V.; Gout, I.T.; Sebire, N.; Marais, R.; Downward, J.; Seckl, M.J. FGF-2 protects small cell lung cancer cells from apoptosis through a complex involving PKCepsilon, BRaf and S6K2. Embo J. 2006, 25, 3078-3088.

170. Ferreira, C.G.; Tolis, C.; Span, S.W.; Peters, G.J.; van Lopik, T.; Kummer, A.J.; Pinedo, H.M.; Giaccone, G. Drug-induced apoptosis in lung cnacer cells is not mediated by the Fas/FasL (CD95/APO1) signaling pathway. Clin. Cancer Res. 2000, 6, 203-212.

171. Bourguignon, L.Y.; Spevak, C.C.; Wong, G.; Xia, W.; Gilad, E. Hyaluronan-CD44 interaction with protein kinase $\mathrm{C}$ (epsilon) promotes oncogenic signaling by the stem cell marker Nanog and the Production of microRNA-21, leading to down-regulation of the tumor suppressor protein PDCD4, anti-apoptosis, and chemotherapy resistance in breast tumor cells. J. Biol. Chem. 2009, 284, 26533-26546.

172. Chmura, S.J.; Dolan, M.E.; Cha, A.; Mauceri, H.J.; Kufe, D.W.; Weichselbaum, R.R. In vitro and in vivo activity of protein kinase $\mathrm{C}$ inhibitor chelerythrine chloride induces tumor cell toxicity and growth delay in vivo. Clin. Cancer Res. 2000, 6, 737-742.

173. Takahashi, I.; Kobayashi, E.; Asano, K.; Yoshida, M.; Nakano, H. UCN-01, a selective inhibitor of protein kinase C from Streptomyces J Antibiot (Tokyo) 1987, 40, 1782-1784.

174. Way, K.J.; Chou, E.; King, G.L. Identification of PKC-isoform-specific biological actions using pharmacological approaches. Trends Pharmacol. Sci. 2000, 21, 181-187.

175. Meyer, T.; Regenass, U.; Fabbro, D.; Alteri, E.; Rosel, J.; Muller, M.; Caravatti, G.; Matter, A. A derivative of staurosporine (CGP 41251 ) shows selectivity for protein kinase C inhibition and in vitro anti-proliferative as well as in vivo anti-tumor activity. Int. J. Cancer 1989, 43, 851-856.

176. Utz, I.; Hofer, S.; Regenass, U.; Hilbe, W.; Thaler, J.; Grunicke, H.; Hofmann, J. The protein kinase C inhibitor CGP 41251, a staurosporine derivative with antitumor activity, reverses multidrug resistance. Int. J. Cancer 1994, 57, 104-110.

177. Budworth, J.; Davies, R.; Malkhandi, J.; Gant, T.W.; Ferry, D.R.; Gescher, A. Comparison of staurosporine and four analogues: Their effects on growth, rhodamine 123 retention and binding to P-glycoprotein in multidrug-resistant MCF-7/Adr cells. Br. J. Cancer 1996, 73, 1063-1068.

178. Selzer, E.; Okamoto, I.; Lucas, T.; Kodym, R.; Pehamberger, H.; Jansen, B. Protein kinase C isoforms in normal and transformed cells of the melanocytic lineage. Melanoma Res. 2002, 12, 201-209.

179. Yoshikawa, N.; Nakamura, K.; Yamaguchi, Y.; Kagota, S.; Shinozuka, K.; Kunitomo, M. Effect of PKC412, a selective inhibitor of protein kinase C, on lung metastasis in mice injected with B16 melanoma cells. Life Sci. 2003, 72, 1377-1387. 
180. Fabbro, D.; Ruetz, S.; Bodis, S.; Pruschy, M.; Csermak, K.; Man, A.; Campochiaro, P.; Wood, J.; O'Reilly, T.; Meyer, T. PKC412--a protein kinase inhibitor with a broad therapeutic potential. Anticancer Drug Des. 2000, 15, 17-28.

181. Fabbro, D.; Buchdunger, E.; Wood, J.; Mestan, J.; Hofmann, F.; Ferrari, S.; Mett, H.; O'Reilly, T.; Meyer, T. Inhibitors of protein kinases: CGP 41251, a protein kinase inhibitor with potential as an anticancer agent. Pharmacol. Ther. 1999, 82, 293-301.

182. Virchis, A.; Ganeshaguru, K.; Hart, S.; Jones, D.; Fletcher, L.; Wright, F.; Wickremasinghe, R.; Man, A.; Csermak, K.; Meyer, T.; Fabbro, D.; Champain, K.; Yap, A.; Prentice, H.G.; Mehta, A. A novel treatment approach for low grade lymphoproliferative disorders using PKC412 (CGP41251), an inhibitor of protein kinase C. Hematol. J. 2002, 3, 131-136.

183. Ganeshaguru, K.; Wickremasinghe, R.G.; Jones, D.T.; Gordon, M.; Hart, S.M.; Virchis, A.E.; Prentice, H.G.; Hoffbrand, A.V.; Man, A.; Champain, K.; Csermak, K.; Mehta, A.B. Actions of the selective protein kinase $\mathrm{C}$ inhibitor PKC412 on B-chronic lymphocytic leukemia cells in vitro. Haematologica 2002, 87, 167-176.

184. Smith, B.D.; Levis, M.; Beran, M.; Giles, F.; Kantarjian, H.; Berg, K.; Murphy, K.M.; Dauses, T.; Allebach, J.; Small, D. Single-agent CEP-701, a novel FLT3 inhibitor, shows biologic and clinical activity in patients with relapsed or refractory acute myeloid leukemia. Blood 2004, 103, 3669-3676.

185. Stone, R.M.; DeAngelo, D.J.; Klimek, V.; Galinsky, I.; Estey, E.; Nimer, S.D.; Grandin, W.; Lebwohl, D.; Wang, Y.; Cohen, P.; Fox, E.A.; Neuberg, D.; Clark, J.; Gilliland, D.G.; Griffin, J.D. Patients with acute myeloid leukemia and an activating mutation in FLT3 respond to a smallmolecule FLT3 tyrosine kinase inhibitor, PKC412. Blood 2005, 105, 54-60.

186. Millward, M.J.; House, C.; Bowtell, D.; Webster, L.; Olver, I.N.; Gore, M.; Copeman, M.; Lynch, K.; Yap, A.; Wang, Y.; Cohen, P.S.; Zalcberg, J. The multikinase inhibitor midostaurin (PKC412A) lacks activity in metastatic melanoma: A phase IIA clinical and biologic study. Br. J. Cancer 2006, 95, 829-834.

187. Keyes, K.A.; Mann, L.; Sherman, M.; Galbreath, E.; Schirtzinger, L.; Ballard, D.; Chen, Y.F.; Iversen, P.; Teicher, B.A. LY317615 decreases plasma VEGF levels in human tumor xenograftbearing mice. Cancer Chemother. Pharmacol. 2004, 53, 133-140.

188. Teicher, B.A.; Alvarez, E.; Menon, K.; Esterman, M.A.; Considine, E.; Shih, C.; Faul, M.M. Antiangiogenic effects of a protein kinase Cbeta-selective small molecule. Cancer Chemother. Pharmacol. 2002, 49, 69-77.

189. Querfeld, C.; Rizvi, M.A.; Kuzel, T.M.; Guitart, J.; Rademaker, A.; Sabharwal, S.S.; Krett, N.L.; Rosen, S.T. The selective protein kinase C beta inhibitor enzastaurin induces apoptosis in cutaneous T-cell lymphoma cell lines through the AKT pathway. J. Invest. Dermatol. 2006, 126, 1641-1647.

190. Rizvi, M.A.; Ghias, K.; Davies, K.M.; Ma, C.; Weinberg, F.; Munshi, H.G.; Krett, N.L.; Rosen, S.T. Enzastaurin (LY317615), a protein kinase Cbeta inhibitor, inhibits the AKT pathway and induces apoptosis in multiple myeloma cell lines. Mol. Cancer Ther. 2006, 5, 1783-1789.

191. Lee, K.W.; Kim, S.G.; Kim, H.P.; Kwon, E.; You, J.; Choi, H.J.; Park, J.H.; Kang, B.C.; Im, S.A.; Kim, T.Y.; Kim, W.H.; Bang, Y.J. Enzastaurin, a protein kinase C beta inhibitor, suppresses 
signaling through the ribosomal S6 kinase and bad pathways and induces apoptosis in human gastric cancer cells. Cancer Res. 2008, 68, 1916-1926.

192. Podar, K.; Raab, M.S.; Zhang, J.; McMillin, D.; Breitkreutz, I.; Tai, Y.T.; Lin, B.K.; Munshi, N.; Hideshima, T.; Chauhan, D.; Anderson, K.C. Targeting PKC in multiple myeloma: in vitro and in vivo effects of the novel, orally available small-molecule inhibitor enzastaurin (LY317615.HCl). Blood 2007, 109, 1669-1677.

193. Spalding, A.C.; Watson, R.; Davis, M.E.; Kim, A.C.; Lawrence, T.S.; Ben-Josef, E. Inhibition of protein kinase Cbeta by enzastaurin enhances radiation cytotoxicity in pancreatic cancer. Clin. Cancer Res. 2007, 13, 6827-6833.

194. Keyes, K.; Cox, K.; Treadway, P.; Mann, L.; Shih, C.; Faul, M.M.; Teicher, B.A. An in vitro tumor model: Analysis of angiogenic factor expression after chemotherapy. Cancer Res. 2002, 62, 5597-5602.

195. Carducci, M.A.; Musib, L.; Kies, M.S.; Pili, R.; Truong, M.; Brahmer, J.R.; Cole, P.; Sullivan, R.; Riddle, J.; Schmidt, J.; Enas, N.; Sinha, V.; Thornton, D.E.; Herbst, R.S. Phase I dose escalation and pharmacokinetic study of enzastaurin, an oral protein kinase $\mathrm{C}$ beta inhibitor, in patients with advanced cancer. J. Clin. Oncol. 2006, 24, 4092-4099.

196. Jirousek, M.R.; Gillig, J.R.; Gonzalez, C.M.; Heath, W.F.; McDonald, J.H. 3rd; Neel, D.A.; Rito, C.J.; Singh, U.; Stramm, L.E.; Melikian-Badalian, A.; Baevsky, M.; Ballas, L.M.; Hall, S.E.; Winneroski, L.L.; Faul, M.M. (S)-13-[(dimethylamino)methyl]-10,11,14,15-tetrahydro-4,9:16, 21-dimetheno-1H, 13H-dibenzo[e,k]pyrrolo[3,4-h][1,4,13] oxadiazacyclohexadecene-1,3(2H)-d ione (LY333531) and related analogues: Isozyme selective inhibitors of protein kinase $\mathrm{C}$ beta. $J$. Med. Chem. 1996, 39, 2664-2671.

197. Kreisl, T.N.; Kotliarova, S.; Butman, J.A.; Albert, P.S.; Kim, L.; Musib, L.; Thornton, D.; Fine, H.A. A phase I/II trial of enzastaurin in patients with recurrent high-grade gliomas. Neuro. Oncol. 2010, 12, 181-189.

198. Robertson, M.J.; Kahl, B.S.; Vose, J.M.; de Vos, S.; Laughlin, M.; Flynn, P.J.; Rowland, K.; Cruz, J.C.; Goldberg, S.L.; Musib, L.; Darstein, C.; Enas, N.; Kutok, J.L.; Aster, J.C.; Neuberg, D.; Savage, K.J.; LaCasce, A.; Thornton, D.; Slapak, C.A.; Shipp, M.A. Phase II study of enzastaurin, a protein kinase $\mathrm{C}$ beta inhibitor, in patients with relapsed or refractory diffuse large B-cell lymphoma. J. Clin. Oncol. 2007, 25, 1741-1746.

199. Mukohara, T.; Nagai, S.; Koshiji, M.; Yoshizawa, K.; Minami, H. Phase I dose escalation and pharmacokinetic study of oral enzastaurin (LY317615) in advanced solid tumors. Cancer Sci. 101, 2193-2199.

200. Rademaker-Lakhai, J.M.; Beerepoot, L.V.; Mehra, N.; Radema, S.A.; van Maanen, R.;Vermaat, J.S.; Witteveen, E.O.; Visseren-Grul, C.M.; Musib, L.; Enas, N.; van Hal, G.; Beijnen, J.H.; Schellens, J.H.; Voest, E.E. Phase I pharmacokinetic and pharmacodynamic study of the oral protein kinase $\mathrm{C}$ beta-inhibitor enzastaurin in combination with gemcitabine and cisplatin in patients with advanced cancer. Clin. Cancer Res. 2007, 13, 4474-4481.

201. Takahashi, I.; Saitoh, Y.; Yoshida, M.; Sano, H.; Nakano, H.; Morimoto, M.; Tamaoki, T. UCN01 and UCN-02, new selective inhibitors of protein kinase C. II. Purification, physico-chemical properties, structural determination and biological activities. J. Antibiot. (Tokyo) 1989, 42, 571-576. 
202. Mizuno, K.; Saido, T.C.; Ohno, S.; Tamaoki, T.; Suzuki, K. Staurosporine-related compounds, K252a and UCN-01, inhibit both cPKC and nPKC. FEBS Lett. 1993, 330, 114-116.

203. Akinaga, S.; Nomura, K.; Gomi, K.; Okabe, M. Effect of UCN-01, a selective inhibitor of protein kinase $\mathrm{C}$, on the cell-cycle distribution of human epidermoid carcinoma, A431 cells. Cancer Chemother. Pharmacol. 1994, 33, 273-280.

204. Graves, P.R.; Yu, L.; Schwarz, J.K.; Gales, J.; Sausville, E.A.; O'Connor, P.M.; Piwnica-Worms, $\mathrm{H}$. The Chk1 protein kinase and the Cdc25C regulatory pathways are targets of the anticancer agent UCN-01. J. Biol. Chem. 2000, 275, 5600-5605.

205. Busby, E.C.; Leistritz, D.F.; Abraham, R.T.; Karnitz, L.M.; Sarkaria, J.N. The radiosensitizing agent 7-hydroxystaurosporine (UCN-01) inhibits the DNA damage checkpoint kinase hChk1. Cancer Res. 2000, 60, 2108-2112.

206. Husain, A.; Yan, X.J.; Rosales, N.; Aghajanian, C.; Schwartz, G.K.; Spriggs, D.R. UCN-01 in ovary cancer cells: Effective as a single agent and in combination with cisdiamminedichloroplatinum(II)independent of p53 status. Clin. Cancer Res. 1997, 3, 2089-2097.

207. Monks, A.; Harris, E.D.; Vaigro-Wolff, A.; Hose, C.D.; Connelly, J.W.; Sausville, E.A. UCN-01 enhances the in vitro toxicity of clinical agents in human tumor cell lines. Invest. New Drugs 2000, 18, 95-107.

208. Tse, A.N.; Schwartz, G.K. Potentiation of cytotoxicity of topoisomerase i poison by concurrent and sequential treatment with the checkpoint inhibitor UCN-01 involves disparate mechanisms resulting in either p53-independent clonogenic suppression or p53-dependent mitotic catastrophe. Cancer Res. 2004, 64, 6635-6644.

209. Dees, E.C.; Baker, S.D.; O'Reilly, S.; Rudek, M.A.; Davidson, S.B.; Aylesworth, C.; Elza-Brown, K.; Carducci, M.A; Donehower, R.C. A phase I and pharmacokinetic study of short infusions of UCN-01 in patients with refractory solid tumors. Clin. Cancer Res. 2005, 11, 664-671.

210. Kortmansky, J.; Shah, M.A.; Kaubisch, A.; Weyerbacher, A.; Yi, S.; Tong, W.; Sowers, R.; Gonen, M.; O'Reilly, E.; Kemeny, N.; Ilson, D.I.; Saltz, L.B.; Maki, R.G.; Kelsen, D.P.; Schwartz, G.K. Phase I trial of the cyclin-dependent kinase inhibitor and protein kinase C inhibitor 7-hydroxystaurosporine in combination with Fluorouracil in patients with advanced solid tumors. J. Clin. Oncol. 2005, 23, 1875-1884.

211. Lara, P.N. Jr.; Mack, P.C.; Synold, T.; Frankel, P.; Longmate, J.; Gumerlock, P.H.; Doroshow, J.H.; Gandara, D.R. The cyclin-dependent kinase inhibitor UCN-01 plus cisplatin in advanced solid tumors: A California cancer consortium phase I pharmacokinetic and molecular correlative trial. Clin. Cancer Res. 2005, 11, 4444-4450.

212. Sausville, E.A.; Arbuck, S.G.; Messmann, R.; Headlee, D.; Bauer, K.S.; Lush, R.M.; Murgo, A.; Figg, W.D.; Lahusen, T.; Jaken, S.; Jing, X.; Roberge, M.; Fuse, E.; Kuwabara, T.; Senderowicz, A.M. Phase I trial of 72-hour continuous infusion UCN-01 in patients with refractory neoplasms. J. Clin. Oncol. 2001, 19, 2319-2333.

213. Hotte, S.J.; Oza, A.; Winquist, E.W.; Moore, M.; Chen, E.X.; Brown, S.; Pond, G.R.; Dancey, J.E.; Hirte, H.W. Phase I trial of UCN-01 in combination with topotecan in patients with advanced solid cancers: A Princess Margaret Hospital Phase II Consortium study. Ann. Oncol. 2006, 17, 334-340. 
214. Schaufelberger, D.E.; Koleck, M.P.; Beutler, J.A.; Vatakis, A.M.; Alvarado, A.B.; Andrews, P.; Marzo, L.V.; Muschik, G.M.; Roach, J.; Ross, J.T. The large-scale isolation of bryostatin 1 from Bugula neritina following current good manufacturing practices. J. Nat. Prod. 1991, 54, 1265-1270.

215. Szallasi, Z.; Denning, M.F.; Smith, C.B.; Dlugosz, A.A.; Yuspa, S.H.; Pettit, G.R.; Blumberg, P.M. Bryostatin 1 protects protein kinase C-delta from down-regulation in mouse keratinocytes in parallel with its inhibition of phorbol ester-induced differentiation. Mol. Pharmacol. 1994, 46, 840-850.

216. Szallasi, Z.; Smith, C.B.; Pettit, G.R.; Blumberg, P.M. Differential regulation of protein kinase C isozymes by bryostatin 1 and phorbol 12-myristate 13-acetate in NIH 3 T3 fibroblasts. J. Biol. Chem. 1994, 269, 2118-2124.

217. Smith, J.B.; Smith, L.; Pettit, G.R. Bryostatins: Potent, new mitogens that mimic phorbol ester tumor promoters. Biochem. Biophys. Res. Commun. 1985, 132, 939-945.

218. Stanwell, C.; Gescher, A.; Bradshaw, T.D.; Pettit, G.R. The role of protein kinase C isoenzymes in the growth inhibition caused by bryostatin 1 in human A549 lung and MCF-7 breast carcinoma cells. Int. J. Cancer 1994, 56, 585-592.

219. Hennings, H.; Blumberg, P.M.; Pettit, G.R.; Herald, C.L.; Shores, R.; Yuspa, S.H. Bryostatin 1, an activator of protein kinase $\mathrm{C}$, inhibits tumor promotion by phorbol esters in SENCAR mouse skin. Carcinogenesis 1987, 8, 1343-1346.

220. Fahrmann, M. Targeting protein kinase C (PKC) in physiology and cancer of the gastric cell system. Curr. Med. Chem. 2008, 15, 1175-1191.

221. Teicher, B.A. Protein kinase $\mathrm{C}$ as a therapeutic target. Clin. Cancer Res. 2006, 12, 5336-5345.

222. Philip, P.A.; Rea, D.; Thavasu, P.; Carmichael, J.; Stuart, N.S.; Rockett, H.; Talbot, D.C.; Ganesan, T.; Pettit, G.R.; Balkwill, F. Phase I study of bryostatin 1: Assessment of interleukin 6 and tumor necrosis factor alpha induction in vivo. The Cancer Research Campaign Phase I Committee. J. Natl. Cancer Inst. 1993, 85, 1812-1818.

223. Jayson, G.C.; Crowther, D.; Prendiville, J.; McGown, A.T.; Scheid, C.; Stern, P.; Young, R.; Brenchley, P.; Chang, J.; Owens, S. A phase I trial of bryostatin 1 in patients with advanced malignancy using a 24 hour intravenous infusion. Br. J. Cancer 1995, 72, 461-468.

224. Propper, D.J.; Macaulay, V.; O'Byrne, K.J.; Braybrooke, J.P.; Wilner, S.M.; Ganesan, T.S.; Talbot, D.C.; Harris, A.L. A phase II study of bryostatin 1 in metastatic malignant melanoma. $\mathrm{Br}$. J. Cancer 1998, 78, 1337-1341.

225. Zonder, J.A.; Shields, A.F.; Zalupski, M.; Chaplen, R.; Heilbrun, L.K.; Arlauskas, P.; Philip, P.A. A phase II trial of bryostatin 1 in the treatment of metastatic colorectal cancer. Clin. Cancer Res. 2001, 7, 38-42.

226. Ajani, J.A.; Jiang, Y.; Faust, J.; Chang, B.B.; Ho, L.; Yao, J.C.; Rousey, S.; Dakhil, S.; Cherny, R.C.; Craig, C.; Bleyer, A. A multi-center phase II study of sequential paclitaxel and bryostatin-1 (NSC 339555) in patients with untreated, advanced gastric or gastroesophageal junction adenocarcinoma. Invest. New Drugs 2006, 24, 353-357.

227. Koutcher, J.A.; Motwani, M.; Zakian, K.L.; Li, X.K.; Matei, C.; Dyke, J.P.; Ballon, D.; Yoo, H.H.; Schwartz, G.K. The in vivo effect of bryostatin-1 on paclitaxel-induced tumor growth, mitotic entry, and blood flow. Clin. Cancer Res. 2000, 6, 1498-1507. 
228. Ku, G.Y.; Ilson, D.H.; Schwartz, L.H.; Capanu, M.; O'Reilly, E.; Shah, M.A.; Kelsen, D.P.; Schwartz, G.K. Phase II trial of sequential paclitaxel and $1 \mathrm{~h}$ infusion of bryostatin-1 in patients with advanced esophageal cancer. Cancer Chemother. Pharmacol. 2008, 62, 875-880.

229. Barr, P.M.; Lazarus, H.M.; Cooper, B.W.; Schluchter, M.D.; Panneerselvam, A.; Jacobberger, J.W.; Hsu, J.W.; Janakiraman, N.; Simic, A.; Dowlati, A.; Remick, S.C. Phase II study of bryostatin 1 and vincristine for aggressive non-Hodgkin lymphoma relapsing after an autologous stem cell transplant. Am. J. Hematol. 2009, 84, 484-487.

230. Mohr, H.; Pettit, G.R.; Plessing-Menze, A. Co-induction of lymphokine synthesis by the antineoplastic bryostatins. Immunobiology 1987, 175, 420-430.

231. Trenn, G.; Pettit, G.R.; Takayama, H.; Hu-Li, J.; Sitkovsky, M.V. Immunomodulating properties of a novel series of protein kinase C activators. The bryostatins. J. Immunol. 1988, 140, 433-439.

232. Peterson, A.C.; Harlin, H.; Karrison, T.; Vogelzang, N.J.; Knost, J.A.; Kugler, J.W.; Lester, E.; Vokes, E.; Gajewski, T.F.; Stadler, W.M. A randomized phase II trial of interleukin-2 in combination with four different doses of bryostatin-1 in patients with renal cell carcinoma. Invest. New Drugs 2006, 24, 141-149.

233. Kedei, N.; Lundberg, D.J.; Toth, A.; Welburn, P.; Garfield, S.H.; Blumberg, P.M. Characterization of the interaction of ingenol 3-angelate with protein kinase C. Cancer Res. 2004, 64, 3243-3255.

234. Hampson, P.; Chahal, H.; Khanim, F.; Hayden, R.; Mulder, A.; Assi, L.K.; Bunce, C.M.; Lord, J.M. PEP005, a selective small-molecule activator of protein kinase $\mathrm{C}$, has potent antileukemic activity mediated via the delta isoform of PKC. Blood 2005, 106, 1362-1368.

235. Cozzi, S.J.; Parsons, P.G.; Ogbourne, S.M.; Pedley, J.; Boyle, G.M. Induction of senescence in diterpene ester-treated melanoma cells via protein kinase $\mathrm{C}$-dependent hyperactivation of the mitogen-activated protein kinase pathway. Cancer Res. 2006, 66, 10083-10091.

236. Serova, M.; Ghoul, A.; Benhadji, K.A.; Faivre, S.; Le Tourneau, C.; Cvitkovic, E.; Lokiec, F.; Lord, J.; Ogbourne, S.M.; Calvo, F.; Raymond, E. Effects of protein kinase C modulation by PEP005, a novel ingenol angelate, on mitogen-activated protein kinase and phosphatidylinositol 3-kinase signaling in cancer cells. Mol. Cancer Ther. 2008, 7, 915-922.

237. Anderson, L.; Schmieder, G.J.; Werschler, W.P.; Tschen, E.H.; Ling, M.R.; Stough, D.B.; Katsamas, J. Randomized, double-blind, double-dummy, vehicle-controlled study of ingenol mebutate gel $0.025 \%$ and $0.05 \%$ for actinic keratosis. J. Am. Acad. Dermatol. 2009, 60, 934-943.

238. Ogbourne, S.M.; Hampson, P.; Lord, J.M.; Parsons, P.; De Witte, P.A.; Suhrbier, A. Proceedings of the First International Conference on PEP005. Anticancer Drugs 2007, 18, 357-362.

239. Ogbourne, S.M.; Suhrbier, A.; Jones, B.; Cozzi, S.J.; Boyle, G.M.; Morris, M.; McAlpine, D.; Johns, J.; Scott, T.M.; Sutherland, K.P.; Gardner, J.M.; Le, T.T.; Lenarczyk, A.; Aylward, J.H.; Parsons, P.G. Antitumor activity of 3-ingenyl angelate: Plasma membrane and mitochondrial disruption and necrotic cell death. Cancer Res. 2004, 64, 2833-2839.

240. Challacombe, J.M.; Suhrbier, A.; Parsons, P.G.; Jones, B.; Hampson, P.; Kavanagh, D.; Rainger, G.E.; Morris, M.; Lord, J.M.; Le, T.T.; Hoang-Le, D.; Ogbourne, S.M. Neutrophils are a key component of the antitumor efficacy of topical chemotherapy with ingenol-3-angelate. $J$. Immunol. 2006, 177, 8123-8132. 
241. Le, T.T.; Gardner, J.; Hoang-Le, D.; Schmidt, C.W.; MacDonald, K.P.; Lambley, E.; Schroder, W.A.; Ogbourne, S.M.; Suhrbier, A. Immunostimulatory cancer chemotherapy using local ingenol-3-angelate and synergy with immunotherapies. Vaccine 2009, 27, 3053-3062.

242. Tanaka, F.; Yamaguchi, H.; Ohta, M.; Mashino, K.; Sonoda, H.; Sadanaga, N.; Inoue, H.; Mori, M. Intratumoral injection of dendritic cells after treatment of anticancer drugs induces tumorspecific antitumor effect in vivo. Int. J. Cancer 2002, 101, 265-269.

243. Saji, H.; Song, W.; Furumoto, K.; Kato, H.; Engleman, E.G. Systemic antitumor effect of intratumoral injection of dendritic cells in combination with local photodynamic therapy. Clin. Cancer Res. 2006, 12, 2568-2574.

244. Lin, J.K. Molecular targets of curcumin. Adv. Exp. Med. Biol. 2007, 595, 227-243.

245. Singh, S.; Khar, A. Biological effects of curcumin and its role in cancer chemoprevention and therapy. Anticancer Agents Med. Chem. 2006, 6, 259-270.

246. Aoki, H.; Takada, Y.; Kondo, S.; Sawaya, R.; Aggarwal, B.B.; Kondo, Y. Evidence that curcumin suppresses the growth of malignant gliomas in vitro and in vivo through induction of autophagy: Role of Akt and extracellular signal-regulated kinase signaling pathways. Mol. Pharmacol. 2007, 72, 29-39.

247. Bachmeier, B.; Nerlich, A.G.; Iancu, C.M.; Cilli, M.; Schleicher, E.; Vene, R.; Dell'Eva, R.; Jochum, M.; Albini, A.; Pfeffer, U. The chemopreventive polyphenol Curcumin prevents hematogenous breast cancer metastases in immunodeficient mice. Cell. Physiol. Biochem. 2007, 19, 137-152.

248. Li, L.; Ahmed, B.; Mehta, K.; Kurzrock, R. Liposomal curcumin with and without oxaliplatin: Effects on cell growth, apoptosis, and angiogenesis in colorectal cancer. Mol. Cancer Ther. 2007, $6,1276-1282$.

249. Li, L.; Braiteh, F.S.; Kurzrock, R. Liposome-encapsulated curcumin: in vitro and in vivo effects on proliferation, apoptosis, signaling, and angiogenesis. Cancer 2005, 104, 1322-1331.

250. Dorai, T.; Dutcher, J.P.; Dempster, D.W.; Wiernik, P.H. Therapeutic potential of curcumin in prostate cancer--V: Interference with the osteomimetic properties of hormone refractory $\mathrm{C} 4-2 \mathrm{~B}$ prostate cancer cells. Prostate 2004, 60, 1-17.

251. Plummer, S.M.; Hill, K.A.; Festing, M.F.; Steward, W.P.; Gescher, A.J.; Sharma, R.A. Clinical development of leukocyte cyclooxygenase 2 activity as a systemic biomarker for cancer chemopreventive agents. Cancer Epidemiol. Biomarkers Prev. 2001, 10, 1295-1299.

252. Cruz-Correa, M.; Shoskes, D.A.; Sanchez, P.; Zhao, R.; Hylind, L.M.; Wexner, S.D.; Giardiello, F.M. Combination treatment with curcumin and quercetin of adenomas in familial adenomatous polyposis. Clin. Gastroenterol. Hepatol. 2006, 4, 1035-1038.

253. Cheng, A.L.; Hsu, C.H.; Lin, J.K.; Hsu, M.M.; Ho, Y.F.; Shen, T.S.; Ko, J.Y.; Lin, J.T.; Lin, B.R.; Ming-Shiang, W.; Yu, H.S.; Jee, S.H.; Chen, G.S.; Chen, T.M.; Chen, C.A.; Lai, M.K.; Pu, Y.S.; Pan, M.H.; Wang, Y.J.; Tsai, C.C.; Hsieh, C.Y. Phase I clinical trial of curcumin, a chemopreventive agent, in patients with high-risk or pre-malignant lesions. Anticancer Res. 2001, 21, 2895-2900.

254. Dhillon, N.; Aggarwal, B.B.; Newman, R.A.; Wolff, R.A.; Kunnumakkara, A.B.; Abbruzzese, J.L.; Ng, C.S.; Badmaev, V.; Kurzrock, R. Phase II trial of curcumin in patients with advanced pancreatic cancer. Clin. Cancer Res. 2008, 14, 4491-4499. 
255. Rafailov, S.; Cammack, S.; Stone, B.A; Katz, A.E. The role of Zyflamend, an herbal antiinflammatory, as a potential chemopreventive agent against prostate cancer: A case report. Integr. Cancer Ther. 2007, 6, 74-76.

256. Dean, N.M.; McKay, R.; Condon, T.P.; Bennett, C.F. Inhibition of protein kinase C-alpha expression in human A549 cells by antisense oligonucleotides inhibits induction of intercellular adhesion molecule 1 (ICAM-1) mRNA by phorbol esters. J. Biol. Chem. 1994, 269, 16416-16424.

257. Nemunaitis, J.; Holmlund, J.T.; Kraynak, M.; Richards, D.; Bruce, J.; Ognoskie, N.; Kwoh, T.J.; Geary, R.; Dorr, A.; Von Hoff, D.; Eckhardt, S.G. Phase I evaluation of ISIS 3521, an antisense oligodeoxynucleotide to protein kinase C-alpha, in patients with advanced cancer. J. Clin. Oncol. 1999, 17, 3586-3595.

258. Villalona-Calero, M.A.; Ritch, P.; Figueroa, J.A.; Otterson, G.A.; Belt, R.; Dow, E.; George, S.; Leonardo, J.; McCachren, S.; Miller, G.L.; Modiano, M.; Valdivieso, M.; Geary, R.; Oliver, J.W.; Holmlund, J. A phase I/II study of LY900003, an antisense inhibitor of protein kinase C-alpha, in combination with cisplatin and gemcitabine in patients with advanced non-small cell lung cancer. Clin. Cancer Res. 2004, 10, 6086-6093.

259. Vansteenkiste, J.; Canon, J.L.; Riska, H.; Pirker, R.; Peterson, P.; John, W.; Mali, P.; Lahn, M. Randomized phase II evaluation of aprinocarsen in combination with gemcitabine and cisplatin for patients with advanced/metastatic non-small cell lung cancer. Invest. New Drugs 2005, 23, 263-269.

260. Paz-Ares, L.; Douillard, J.Y.; Koralewski, P.; Manegold, C.; Smit, E.F.; Reyes, J.M.; Chang, G.C.; John, W.J.; Peterson, P.M.; Obasaju, C.K.; Lahn, M.; Gandara, D.R. Phase III study of gemcitabine and cisplatin with or without aprinocarsen, a protein kinase C-alpha antisense oligonucleotide, in patients with advanced-stage non-small-cell lung cancer. J. Clin. Oncol. 2006, 24, 1428-1434.

261. Stockwin, L.H.; Yu, S.X.; Stotler, H.; Hollingshead, M.G.; Newton, D.L. ARC (NSC 188491) has identical activity to Sangivamycin (NSC 65346) including inhibition of both P-TEFb and PKC. BMC Cancer 2009, 9, 63.

262. Slavik, M. Nucleoside analogs in the treatment of neoplastic and nonneoplastic diseases. Ann. $N$. Y. Acad. Sci. 1975, 255, 266-268.

263. Robins, R.K.; Revankar, G.R. Purine analogs and related nucleosides and nucleotides as antitumor agents. Med. Res. Rev. 1985, 5, 273-296.

264. Uberall, F.; Maly, K.; Egle, A.; Doppler, W.; Hofmann, J.; Grunicke, H.H. Inhibition of cell proliferation, protein kinase $\mathrm{C}$, and phorbol ester-induced fos expression by the dihydropyridine derivative B859-35. Cancer Res. 1991, 51, 5821-5825.

265. Van Ummersen, L.; Binger, K.; Volkman, J.; Marnocha, R.; Tutsch, K.; Kolesar, J.; Arzoomanian, R.; Alberti, D.; Wilding, G. A phase I trial of perifosine (NSC 639966) on a loading dose/maintenance dose schedule in patients with advanced cancer. Clin. Cancer Res. 2004, 10, 7450-7456.

266. Cen, D.; Brayton, D.; Shahandeh, B.; Meyskens, F.L. Jr.; Farmer, P.J. Disulfiram facilitates intracellular $\mathrm{Cu}$ uptake and induces apoptosis in human melanoma cells. J. Med. Chem. 2004, 47, 6914-6920. 
267. Chu, F.; O'Brian, C.A. PKC sulfhydryl targeting by disulfiram produces divergent isozymic regulatory responses that accord with the cancer preventive activity of the thiuram disulfide. Antioxid. Redox Signal. 2005, 7, 855-862.

268. Fruehauf, J.P.; Meyskens, F.L. Jr. Reactive oxygen species: A breath of life or death?. Clin. Cancer Res. 2007, 13, 789-794.

269. Fruehauf, J.P.; Trapp, V. Reactive oxygen species: An Achilles' heel of melanoma? Expert Rev. Anticancer Ther. 2008, 8, 1751-1757.

(C) 2011 by the authors; licensee MDPI, Basel, Switzerland. This article is an open access article distributed under the terms and conditions of the Creative Commons Attribution license (http://creativecommons.org/licenses/by/3.0/). 